\title{
Business Model Innovation Through the Lens of Time: An Empirical Study of Performance Implications Across Venture Life Cycles
}

\author{
Elena Freisinger • Sven Heidenreich (D) - Christian Landau • \\ Patrick Spieth
}

Accepted: 2 September 2021 / Published online: 28 October 2021

(C) The Author(s) 2021

\begin{abstract}
Current literature suggests that the innovation of a business model is among the most important success factors for organizations and has a positive influence on their performance. What is not yet clear, however, is how this relationship unfolds during an organization's life cycle. We posit that business model innovation strongly contributes to firm performance in earlier phases, but ultimately gets less important. We therefore collected data on 250 organizations in Germany and used structural equation modeling for analytical purposes. We make the following two main contributions to the literature: (1) We confirm recent findings about the positive impact of business model innovation on performance; (2) we provide first empirical evidence for the important role of life cycle stages as moderator with regard to this relationship. With respect to the latter, our findings show that business model innovation is an important pathway of organizations, especially in their early years of existence, yet somewhat diminishing over time. In conclusion, this study opens
\end{abstract}

This paper was originally submitted and independently peer-reviewed at Business Research, one of SBUR's predecessor journals. It has been accepted by the same Editor-in-Chief for publication in the successor journal SBUR.

\footnotetext{
Elena Freisinger

Technische Universität Ilmenau, Ehrenbergstraße 29, 98693 Ilmenau, Germany

E-Mail: elena.freisinger@tu-ilmenau.de

Sven Heidenreich $(\bowtie)$

Universität des Saarlandes, Campus C3 1, 66123 Saarbrücken, Germany

E-Mail: sven.heidenreich@uni-saarland.de

Christian Landau

EBS Business School, Rheingaustraße 1, 65375 Oestrich-Winkel, Germany

E-Mail: christian.landau@ebs.edu

Patrick Spieth

Universität Kassel, Kleine Rosenstraße 3, 34117 Kassel, Germany

E-Mail: spieth@uni-kassel.de
} 
new research avenues by extending and incorporating explanations for the life cycle theory and business model innovation.

Keywords Life cycle stages $\cdot$ Business model $\cdot$ Business model innovation $\cdot$ Firm performance

JEL M13

\section{Introduction}

Novel business models appear to play an important role in disrupting entire industry dynamics and changing "the way people live, work, consume, and interact with each other" (Demil et al. 2015, p. 2). Uber, for example, a new venture founded in 2009, bypassed the traditional licensing system of taxi companies by offering a locationbased app that allows individuals to hire a private on-demand driver (de Jong and van Dijk 2015). Similarly, bitcoin-based business models successfully disrupted the way traditional banking institutes made business for decades (de Jong and van Dijk 2015). Anecdotal evidence shows that profitable business models do not necessarily entail a better or more innovative product, but change the game of the industry (Afuah 2014). Hence, it is not surprising that design of successful novel business models have turned into a key strategic priority for managers in multiple industries (Chesbrough 2007; Johnson et al. 2008; Massa et al. 2017). Managers of incumbent firms and entrepreneurs are increasingly using the business model concept in order to understand and to rethink novel ways on how to achieve their company's goals (Laudien and Daxböck 2017; Massa et al. 2017). Yet, not only in practice but also in academia, business models are a largely discussed topic spanning almost all disciplines of economics, e.g., technology and innovation management (e.g. Tripsas and Gavetti 2000; Tucci and Massa 2013), strategy (e.g. Casadesus-Masanell and Zhu 2013; Suh et al. 2020; Teece 2010), and sustainability (e.g. França et al. 2016; Klein et al. 2021; Snihur 2016). Ever since the concept has firstly been brought to academia, business model innovation (BMI) is considered as a source of competitive advantage (Casadesus-Masanell and Zhu 2013; Demil and Lecocq 2010; Teece 2010) that ultimately leads to financial performance (Foss and Saebi 2017). This prominent link is somewhat the crux, but also the cornerstone of business model research.

Up until 2021, research on BMI is still very much on the rise fueled through recent empirical studies showing that BMIs are a source of competitiveness and competitive advantage (Clauss et al. 2019a; Teece 2010; Wirtz et al. 2010), with "the potential to improve enterprise performance" (Lambert and Davidson 2013, p. 676) or even change the market equilibrium (Trabucchi et al. 2019). As a result, in the last twenty years, a growing body of literature is showing a strong interest in BMI denoted as a "new subject of innovation, which complements the traditional subjects of process, product, and organizational innovation" (Zott et al. 2011, p. 1032). However, besides many others, especially the effect-side of BMI has been paid considerable attention to, but a systematic understanding on how BMI contributes to firm success is still lacking (Foss and Saebi 2017). So far, only a handful studies 
were able to describe this widely-stated association but mainly in a correlational way and without considering the dimension of time (Foss and Saebi 2017, 2018). Yet, almost twenty years after the advent of business model research, it is still not clear, whether BMI is beneficial to the firm at all (Foss and Saebi 2017, 2018). What we know so far is largely based upon empirical studies that investigate how different business model designs contribute to performance effects (e.g., Wei et al. 2014; Zott and Amit 2007, 2008). Current studies have shown that environmental factors, e.g., environmental dynamism (Pati et al. 2018), environmental turbulence (Schrauder et al. 2018), and environmental resource munificence (Zott and Amit 2007) influence the relationship. Yet, besides a handful studies, effect-side BMI research has failed to examine contextual factors, such as firm age, firm size, firm characteristics as well as a firm's focal value proposition. First empirical studies acknowledge that performance implications differ across firms in their early or late life cycle stages in case of a more efficiency-centered business model design (Brettel et al. 2012), a paucity of studies, however, remains investigating the impact of the innovativeness of the business model on performance implications for new ventures and more established firms. In a similar vein, research has so far lacked to account for different firm-types, i.e., product- or service-oriented firms, and how their engagement in BMI and the resulting performance implications varies for new and more mature ventures.

In order to improve our understanding, this paper explores the prominent relationship between BMI and firm performance by (1) providing a systematic literature review of empirical studies investigating this relationship, (2) presenting further empirical evidence on the beneficial character of BMI, (3) examining the moderating influence of early and late life cycle stages, and (4) comparing the findings for product- and service-oriented BMIs. We therefore collected data on 250 new and more mature ventures in Germany and used structural equation modeling for analytical purposes. We make the following two main contributions to the literature: (1) we add further evidence to the body of knowledge of effect-side research of BMI, and (2) we bring new contingency factors into the discussion. The paper first gives a systematic literature review, followed by hypotheses derivation. The next section emphasizes the study's research design and methodology, afterwards we present our results. The last section draws these findings together, discusses its implications for theory, as well as for practice, and concludes with limitations and avenues for further research.

\section{Systematic Literature Review}

\subsection{Systematic Literature Review of the Effect-side of BMI Research}

In order to grasp the amount of current knowledge on the relationship between BMI and firm performance, we conducted a systematic literature review using the procedure suggested by Denyer and Tranfield (2009). By executing a systematic search in three scientific databases, namely in EBSCO Business Source Complete, ElsevierScience Direct, and Scopus, we not only focused on the search term "business model innovation", but also included the expression(s) "business model design", "business 


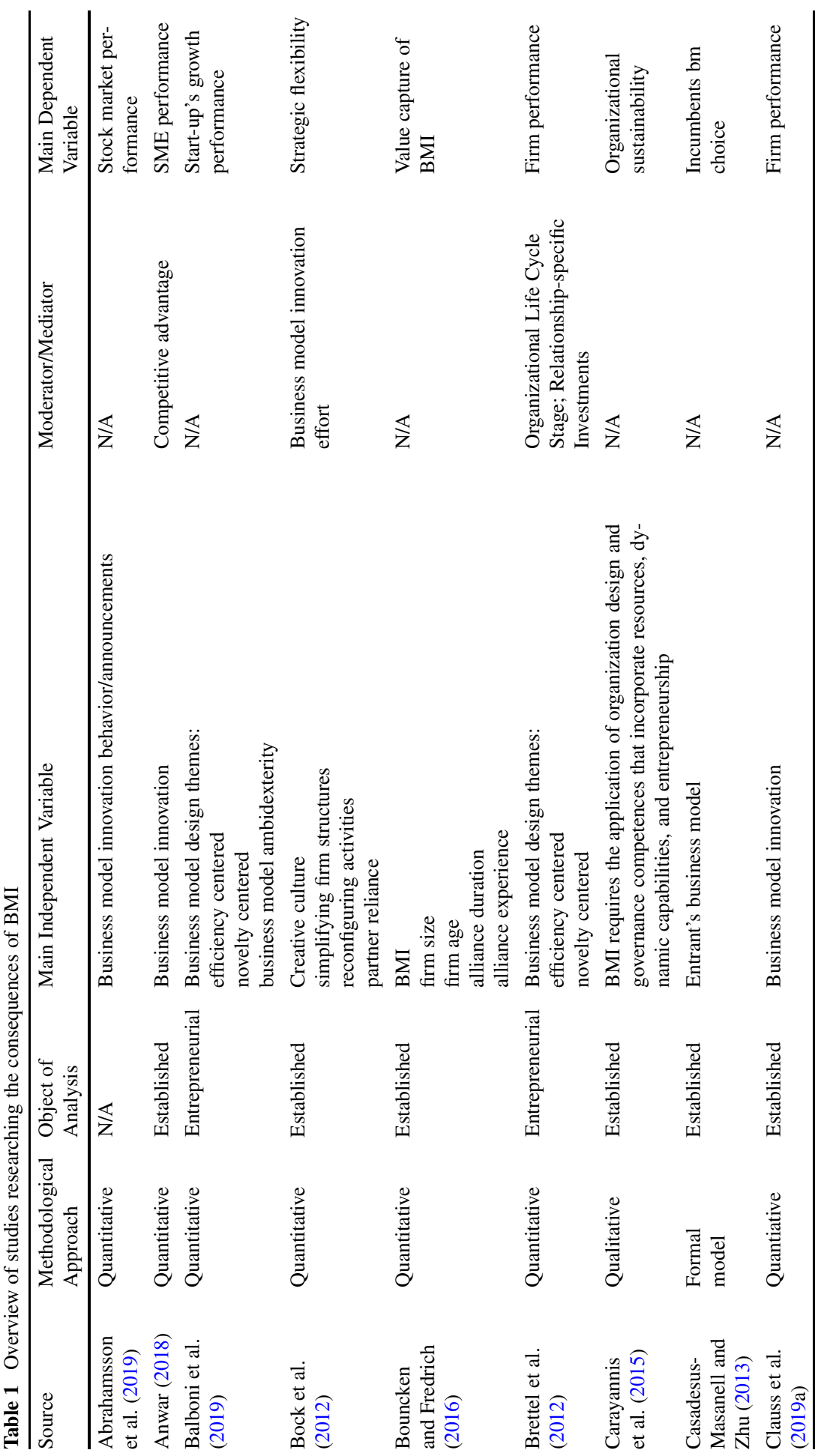




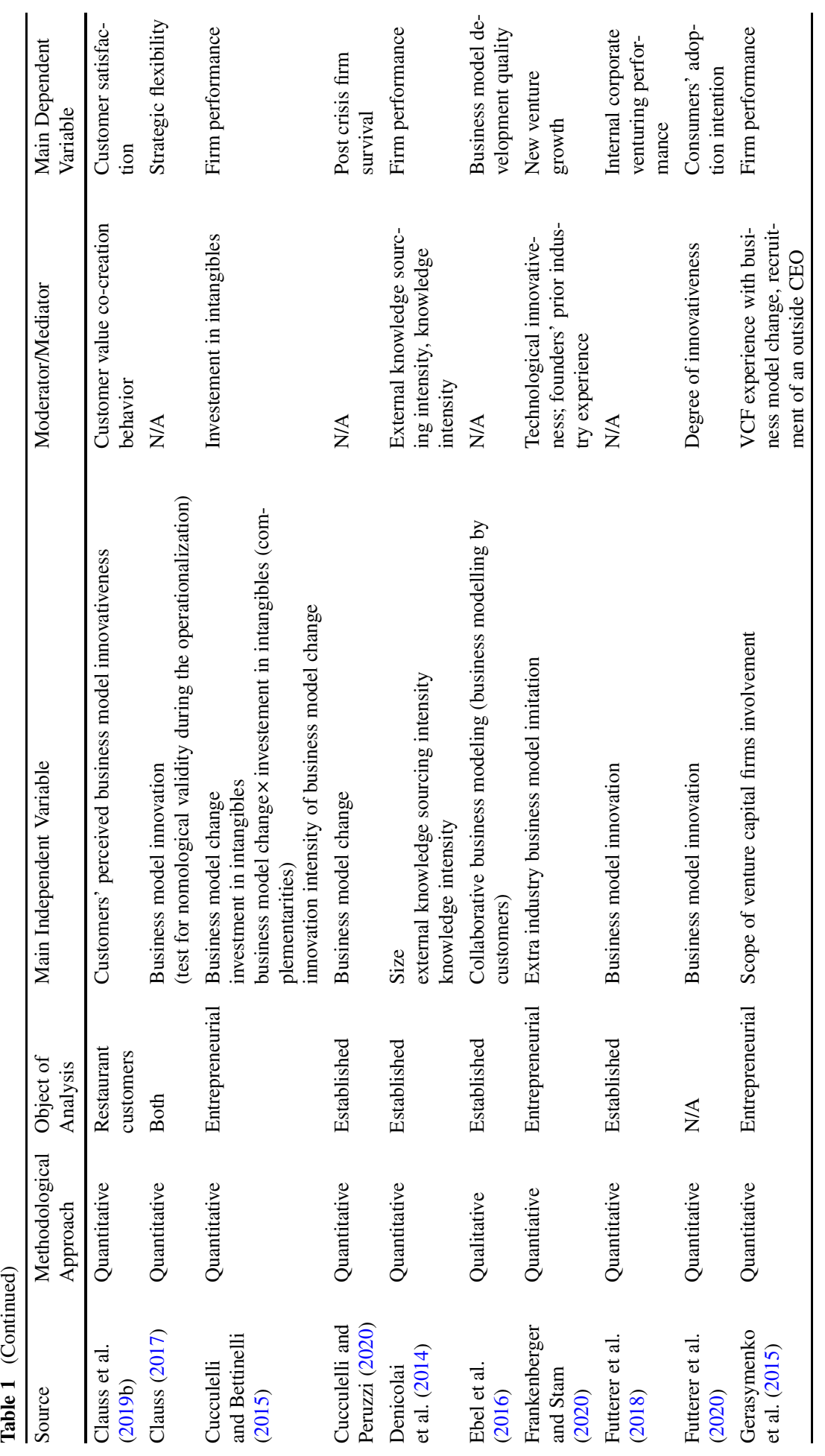




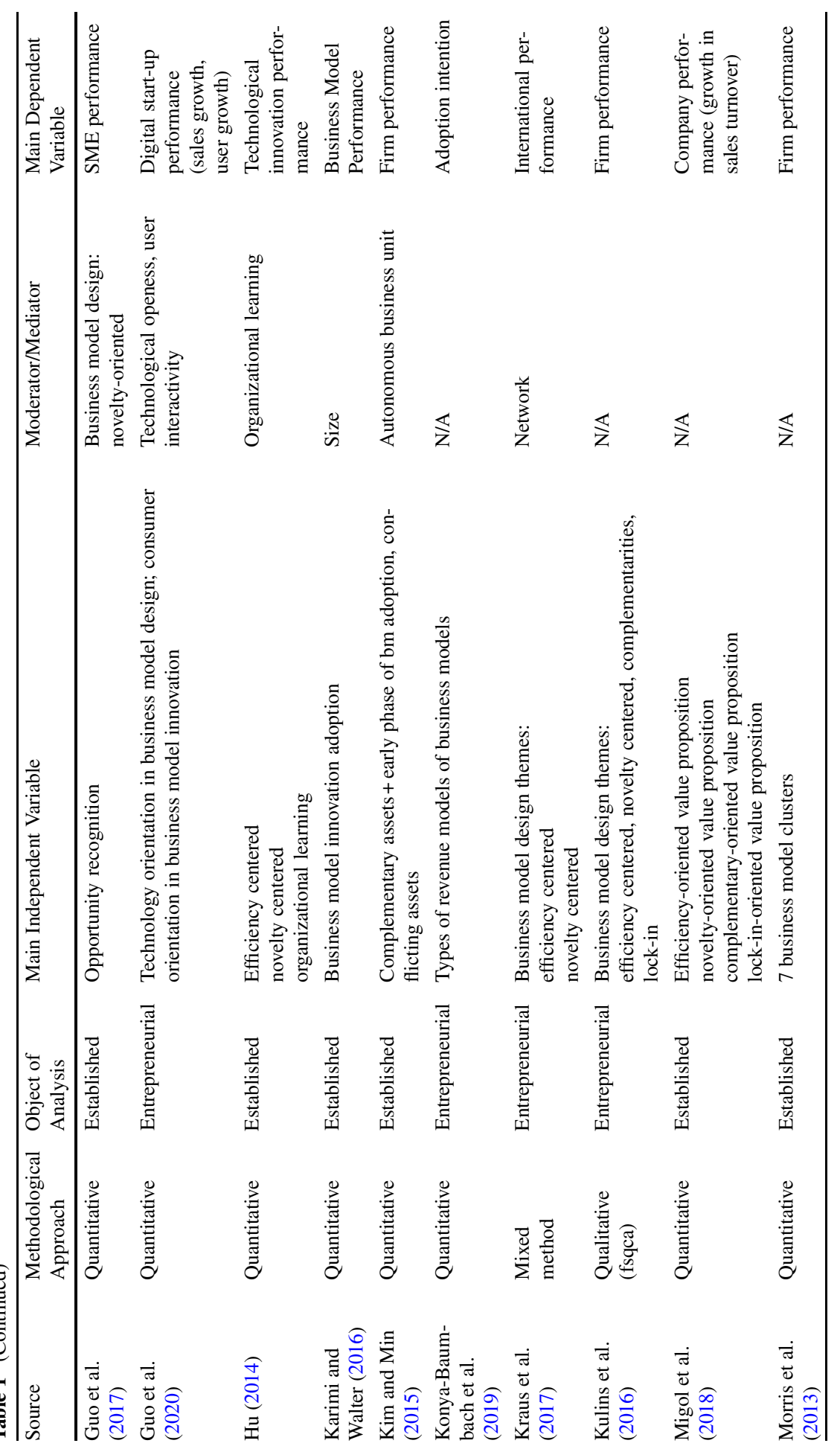




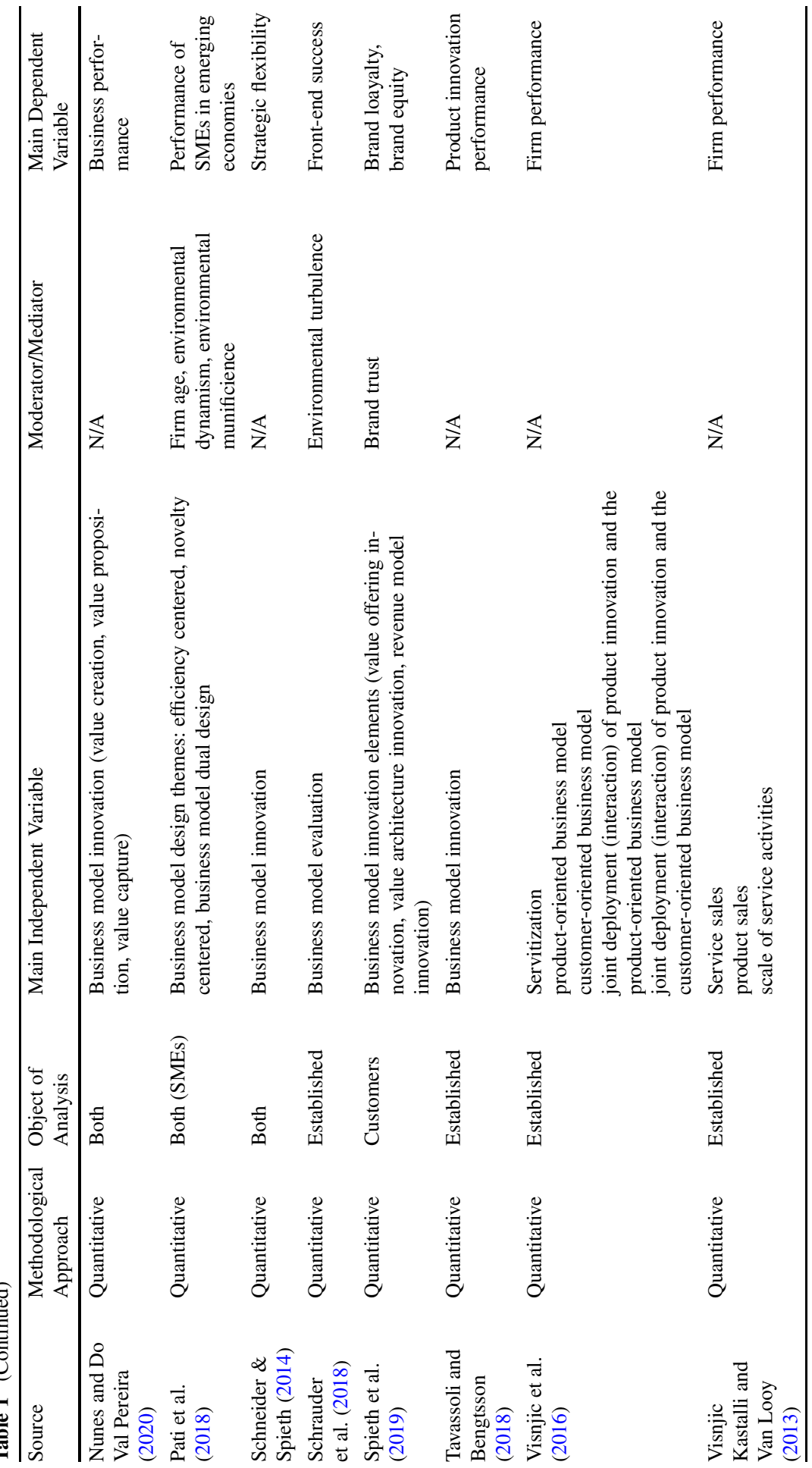




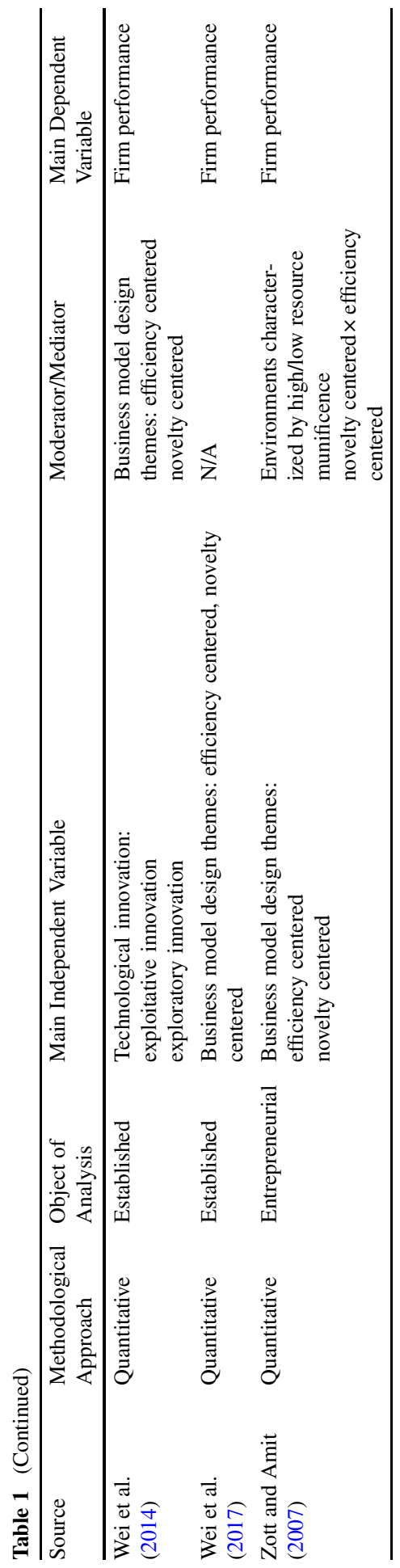


model development", "business model renewal" or "business model change" which are used interchangeably for the same phenomenon (Foss and Saebi 2017). The search terms had to be included either in the title, the abstract, or in the keywords of peer-reviewed articles between 2000 and December 2020 and by that we identified 1676 articles after removing duplicates. In a next step, we applied an objective criterion (Denyer and Tranfield 2009) to assess the relevance of each study. More specifically, we excluded articles which were not ranked A+, A, or B in the VHBJOURQUAL $^{1}$ ranking to ensure quality as well as theory-focused work. However, we included all articles from the Journal of Business Models, a journal devoted to establishing the discipline of business models as a separately recognized core discipline to get a thorough picture of the literature. This resulted in a total of 397 articles. Furthermore, we reviewed and coded the remaining articles using the MAXQDA software and eliminated publications without a primary focus on BMI; 260 articles were eventually deemed as a fit for our research purpose. We again reviewed and assigned these articles into the categories of antecedents, process, construct, and effects. We found a large volume of published studies describing the role of organizational and individual antecedents $(n=85)$, research investigating the act of designing and implementing BMIs $(n=75)$, and investigations into the construct itself $(n=75)$. However, only a small proportion of studies has devoted its attention to the effect-side of BMI $(n=40)$, yet with a certain increase in recent years (for an overview see Table 1).

What we know about BMI performance relationship is largely based upon four types of empirical studies that investigate how BMI impacts performance. The first type encompasses the activity system view (Zott and Amit 2010) and investigates how different design themes (Zott and Amit 2007) impact performance variables such as firm performance (Brettel et al. 2012; Wei et al. 2017), technological innovation performance (Hu 2014), start-up's growth performance (Balboni et al. 2019), or small and medium-sized enterprise (SME) performance (Pati et al. 2018). Another stream of effect-side research, the element-based view (Clauss et al. 2019b) connects the innovativeness of the business model with different outcomes, such as strategic flexibility (Spieth and Schneider 2016), internal corporate venturing performance (Futterer et al. 2018), and again firm performance (Clauss et al. 2019a). A third type of studies examines the effects of different aspects that come along with BMI, such as different types of revenue models (Konya-Baumbach et al. 2019), productand service-orientation (Visnjic et al. 2016), or technology and consumer orientation in BMIs (Guo et al. 2020), as well as business model adoption (Karimi and Walter 2016) and business model imitation behavior (Frankenberger and Stam 2020). While these study entail an inside-firm perspective, the fourth type and more recent research shift to a customer-oriented view and examine the effects of BMI on customer satisfaction (Clauss et al. 2019b), adoption intention (Futterer et al. 2020), and brand loyalty (Spieth et al. 2019).

\footnotetext{
1 The VHB-JOURQUAL Rating is a journal ranking of the German scientific community. The scientific quality of a journal is defined as the extent to which the journal in question advances business administration as a scientific discipline. The categories A and B in this ranking do largely correspond with the categories 4 and 3 in the ABS journal ranking.
} 
With respect to potential benefits, these studies point to the fact that BMI is a powerful predictor for firm performance (Cucculelli and Bettinelli 2015; Karimi and Walter 2016; Visnjic et al. 2016). However, many questions remain in this young field of study. First, while the majority of the studies connects different business model designs with firm performance, more research is needed examining the impact of the innovativeness of business models within the element-based view. There are relatively few current studies that indeed present first evidence for the beneficial character but replicating these studies in different contexts might shed new light on the most prominent statement in the BMI literature. Second, while few studies have integrated contingency and moderating variables in their research, there are many factors that may influence the strength of that effect. Current studies have shown that environmental factors, e.g., environmental dynamism (Pati et al. 2018), environmental turbulence (Schrauder et al. 2018), and environmental resource munificence (Zott and Amit 2007), influence the relationship. Yet, besides a handful studies, effect-side BMI research has failed to examine contextual factors, such as firm age, firm size, firm characteristics as well as a firm focal value proposition. Yet, in combination with an element-based approach, the exploration of contextual factors holds the potential to deepen our understanding of the BMI performance relationship. Previous studies have indicated that BMI performance relationship is especially contingent on the factor time (Balboni et al. 2019; Foss and Saebi 2017; Pati et al. 2018), but a clear understanding of the impact on the effect strength is still missing. In the following, we will first discuss the core assumptions of BMI research and subsequently develop an understanding on how different life cycle stages affect this relationship and discuss how this relationship might further vary for productand service-oriented BMIs.

\subsection{Business Model and Business Model Innovation}

For a long time, business models have mainly been used as a template or narrative device to understand and communicate a firm's current activities by managers (Massa et al. 2017). In 2003, Mitchell and Coles moved the idea of managers having the ability to purposefully change a business model into the spotlight (Foss and Saebi 2017). By adding the additional dimension of innovation (Foss and Saebi 2017), business models have eventually become a potential unit of innovation that "complements the traditional subjects of process, product, and organizational innovation" (Zott et al. 2011, p. 1032). A business model is a formal conceptual representation of a company (Massa et al. 2017) and thereby reflects the "design or architecture of the value creation, delivery, and capture mechanisms" of a firm (Teece 2010, p. 172). In terms of conceptualization, two dominant views have emerged (Clauss et al. 2019b): the activity system perspective (Casadesus-Masanell and Ricart 2010; Zott and Amit 2010) views business models as holistic systemic structures that encompass all activities of a company as well as how and when these activities are carried out (Zott and Amit 2010); the element-based perspective approaches the business model construct as a modular set of elements consisting of three (Bocken et al. 2013; Clauss 2017; Spieth and Schneider 2016) or of four elements (Baden-Fuller and Haefliger 2013; Futterer et al. 2018; Johnson et al. 2008; Osterwalder et al. 2010). This under- 
standing is rooted in the dynamic perspective on business models (e.g., CasadesusMasanell and Ricart 2010; Demil and Lecocq 2010; Martins et al. 2015), which refers to dynamic interactions among various business model elements (CasadesusMasanell and Ricart 2010; Demil and Lecocq 2010). In the following, we will draw on latter one as the element-based view is generally considered as the cornerstone for BMI research (Clauss 2017; Futterer et al. 2018; Spieth and Schneider 2016). According to the element-based view, business models consists of four interrelated elements, namely (1) value offering, (2) internal value creation, (3) external value creation, and (4) financial architecture (Futterer et al. 2018) that capture a firm's foundational processes (Foss and Saebi 2017, 2018; Saebi et al. 2017). The first element, which reflects the value offering of a company, comprises the products and services offered to the target market (Demil and Lecocq 2010; Yunus et al. 2010), the internal value creation element integrates the methods, processes, structures, and competencies within the company's value chain (Demil and Lecocq 2010; Dubosson-Torbay et al. 2002; Osterwalder et al. 2005), the third element- the external value creation-describes the relationships with external partners, stakeholders, and distribution channels (Kindström 2010; Yunus et al. 2010) and the financial architecture element constitutes the company's revenue mechanisms and cost structure (Chesbrough 2007; Osterwalder et al. 2005; Yunus et al. 2010).

BMI itself is a transformation process that purposely alters the key elements of a business model (Bucherer et al. 2012; Clauss et al. 2019a; Tucci and Massa 2013) and nontrivial changes to these key elements of a firm's business model eventually result in a BMI (Foss and Saebi 2017). Firms can either innovate single elements or introduce a whole new business model (Foss and Saebi, 2017). While changing "of at least one core element is the necessary condition for BMI to be given, the sufficient condition is represented by a subsequent change of the BM's underlying logic" (Futterer et al. 2018, p. 2). Since even the change of one core element induces (minor) changes in other elements as well (Demil and Lecocq 2010; Johnson et al. 2008), innovating only one element often requires reconfigurations of the business logic and thus may constitute BMI (Foss and Saebi 2017). In case of established firms, BMI is deemed either the change of an established business model (Amit and Zott 2012; Zott and Amit 2013) or the creation of a new innovative business model that is added to their portfolio (Snihur and Tarzijan 2018). For new ventures, BMI is typically the creation of a new innovative business model (Foss and Saebi 2018, 2017). Eventually, the reference point for the innovation is either its newness to the firm or its newness to the industry (Foss and Saebi 2017).

\section{Conceptual Development}

\subsection{Business Model Innovation and Firm Performance}

Innovation means "doing something new", e.g., developing new products, new processes, new markets (Schumpeter 1934), and now new business models (Taran et al. 2015). In new product contexts, innovation is considered as the extent a new product differs from already existing ones (e.g., Cillo et al. 2010; Cooper and Kleinschmidt 
1987; Danneels and Kleinschmidtb 2001), meaning innovativeness is the difference between old and new (Garcia and Calantone 2002). More precisely, innovativeness covers the amount of newness relative to a certain base, such as the world, the industry, the firm, or the perception of the customer (Calantone et al. 2006; Garcia and Calantone 2002). In case of business models, innovativeness captures the relative amount of newness to the focal firm (e.g., Osterwalder et al. 2005; Spieth and Schneider 2016) or to the industry (Amit and Zott 2012; Snihur and Tarzijan 2018) depending on the perspective. Hence, following the interpretation that business models are attributes of real firms, being innovative in doing business means executing value-adding activities such as value creation and/or value capture (Massa et al. 2017) in the core elements of a business model, namely value offering, internal value creation, external value creation, and financial architecture.

According to Lepak et al. "value creation depends on the relative amount of value that is subjectively realized by a target user (or buyer) who is the focus of value creation - whether individual, organization, or society - and that this subjective value realization must at least translate into the user's willingness to exchange a monetary amount for the value received" (Lepak et al. 2007, p. 182). The value creation is typically described in the most integral part of a business model in the value offering element that comprises the products and services offered to the target market (Futterer et al. 2018). Such changes optimize the resources and competencies employed more toward customers' preferences and are more tailored toward customers' needs, enhancing customer satisfaction (Futterer et al. 2020). By innovating the value creation in a way that it delivers greater value to the target market a company is able to outperform its competitors (Normann and Ramirez 1994, 1993; Porter 1985). Furthermore, business models also describe the value capture domain: "value may be captured by the use of resources with attributes that make them difficult to imitate, through the source's own use of creative destruction before competitors can use the innovation, and through methods of resource management" (Lepak et al. 2007, p. 189). Value creation in business models is reflected in the internal value chain, relationships with external partners, and the financial architecture of a company; i.e., all activities necessary to monetize the value created (Massa et al. 2017). Hence, being more innovative in the respective business models elements, leads to cost reduction, process optimization, accessing new markets, and eventually to financial performance improvements (Foss and Saebi 2017). This indicates a positive link between business model innovativeness and financial performance improvements.

Therefore, we assume the following-

\section{H1: BMI has a positive effect on firm performance.}

\subsection{Business Model Innovation and Life Cycle Stages}

While prior research often emphasizes BMI as the holy grail for achieving firm performance, more recent research indicates that innovated business models are not always necessarily better than existing business models, such that positive performance implications often strongly depend on contingency factors (CasadesusMasanell and Ricart 2010; Futterer et al. 2020; Kranich and Wald 2018). Under- 
standing the contingency mechanisms that unfold BMI into positive firm performance implications is of utmost importance for many firms. Yet, effect-side BMI research neglected to thoroughly discuss contingency factors of this valuable relationship. So far, recent research acknowledges that the performance implications of firms might differ across early and late life cycle stages depending on the business model design, i.e., either novelty- or efficiency-based, they have chosen (Brettel et al. 2012). Yet a more in-depth understanding is still missing. Both, young ventures and more established firms possess a unique bundle of resources and capabilities depending on their individual life stage that provide benefits and weaknesses (Carr et al. 2010). These benefits and weaknesses have an influence on the ventures capability to create and capture value from its BMI (Pati et al. 2018). Organizations grow in a predictable pattern (Hanks et al. 1993) and move through different life cycle stages (e.g., Gaibraith 1982; Kazanjian 1988; Laudien and Daxböck 2017; Quinn and Cameron 1983; Smith et al. 1985). Every venture's life begins with a startup or birth stage, moves through certain growth stages, and ends with a form of maturity or with the decline of an organization (Hanks et al. 1993). Due to conceptual vagueness and a lack of distinctness concerning the individual stages (Hanks et al. 1993), scholars typically differentiate the early and late life cycle stages of ventures (e.g., Brettel et al. 2012; Dodge et al. 1994; Engelen et al. 2010).

More established firms have typically gained some form of stability and execute a viable and working business model. These firms typically capture more value from their experiences, well-functioning processes, established routines and longterm partnerships (Kotha et al. 2011). In case of more established SMEs-or firms in their later life cycle stages-BMI means either the change of an existing business model (Amit and Zott 2012; Zott and Amit 2013) or the creation of a new innovative business model that is added to its portfolio (Snihur and Tarzijan 2018). This may happen due to several reasons, e.g., new entrants in the market (Dewald and Bowen 2010), disrupting power of new technologies (Sabatier et al. 2012) or a general emphasis on innovation in a company (Sorescu et al. 2011). Firms in their later life cycle stages have already gained a good sense of their environment, such as their market, customers, and partners (Zahra and George 2002). However, changing an existing business model, like Xerox did when switching from selling copiers to leasing them (Chesbrough and Rosenbloom 2002), comes also with idiosyncratic challenges for the innovating firm, such as path dependencies, organizational inertia, new management processes, and types of organizational learning (Tucci and Massa 2013). The performance effects realized through a BMI might get mitigated by the transition process the company undergoes.

In contrast, new ventures, or firms in their early life cycles stages, are typically created to pursue unexploited opportunities (Dahlqvist and Wiklund 2012), are characterized by smaller firm size, lower age, a more uncertain environment and a different structure (Brettel et al. 2012), and have to take on a long journey before overcoming their liability of newness (Stinchcombe 1965). In new ventures, business models are an important device to narrow down the initial entrepreneurial idea into a describable opportunity (George and Bock 2011). In case of new ventures, BMI means the deployment of an innovative business model right from their inception (Foss and Saebi 2017). The reference point for innovation in this case is 
the industry. Uber, for example, outperformed established taxi companies, that offered the traditional licensing system, by providing a location-based app and a taxi service via private drivers (de Jong and van Dijk 2015). By being more innovative with their business models than their competitors, they are doing better in creating and capturing value, which ultimately leads to greater firm performance. We argue that this effect is stronger for young ventures in their early life stages for several reasons. First, new ventures tend to have a stronger business sense with less complex decision-making mechanisms, less inefficiencies in their processes, and less rigid structures (Thornhill and Amit 2003). Furthermore, younger ventures deploy an atmosphere of creativity and have clearer information channels (Zaheer and Bell 2005). New ventures have not yet built formalized processes and standardized work procedures (Engelen et al. 2010), since they have to constantly adapt to new and unknown situations (Roure and Keeley 1990). These characteristics of ventures in their early years of existence suggest that they are in a more favorable position to benefit from innovation-related opportunities (Rosenbusch et al. 2011), BMI being one of them. While many new business models fail, before a new one becomes viable, these new ventures with their innovative business models are sources of abnormal returns (Tucci and Massa 2013).

Hence, we conclude that early stage firms might create and capture greater value from BMI and transform it into performance.

Therefore, we assume the following-

H2: In early stages, BMI has stronger effects on firm performance than in later stages.

\subsection{Business Model Innovation and Product- and Service-oriented Firm Types}

Previous studies have already identified that BMI has a different impact on performance implications, depending on whether BMIs are product- or service-oriented (e.g., Visnjic et al. 2016; Visnjic Kastalli et al. 2013). However, previous studies have not yet determined how these effects unfold in early and late stages of a venture's life.

Service-oriented firms are characterized by intangible products and focus on a more people-oriented business (Masurel and Van Montfort 2006). In their early life cycle stages their diversification of object types, clients, and activities is typically rather small (Masurel and Van Montfort 2006) and it is crucially important to implement and market their innovative business model. In the later stages, serviceoriented firms have typically gained broader diversification, more stable relationships with their customers, and deal with a larger variety of markets, clients, as well as sectors (Masurel and Van Montfort 2006). Hence, BMI becomes less important for service-oriented firms, due to other value drivers with greater impact in later stages. In contrast to service-oriented firms, ventures with a greater focus on more tangible assets engage more in product innovation, which is considered as one of the main drivers of value creation (Visnjic et al. 2016). However, sole product innovation is deemed less profitable than product innovation embedded in the appropriate business model (Chesbrough and Rosenbloom 2002; Teece 2010). Product-oriented firms in 


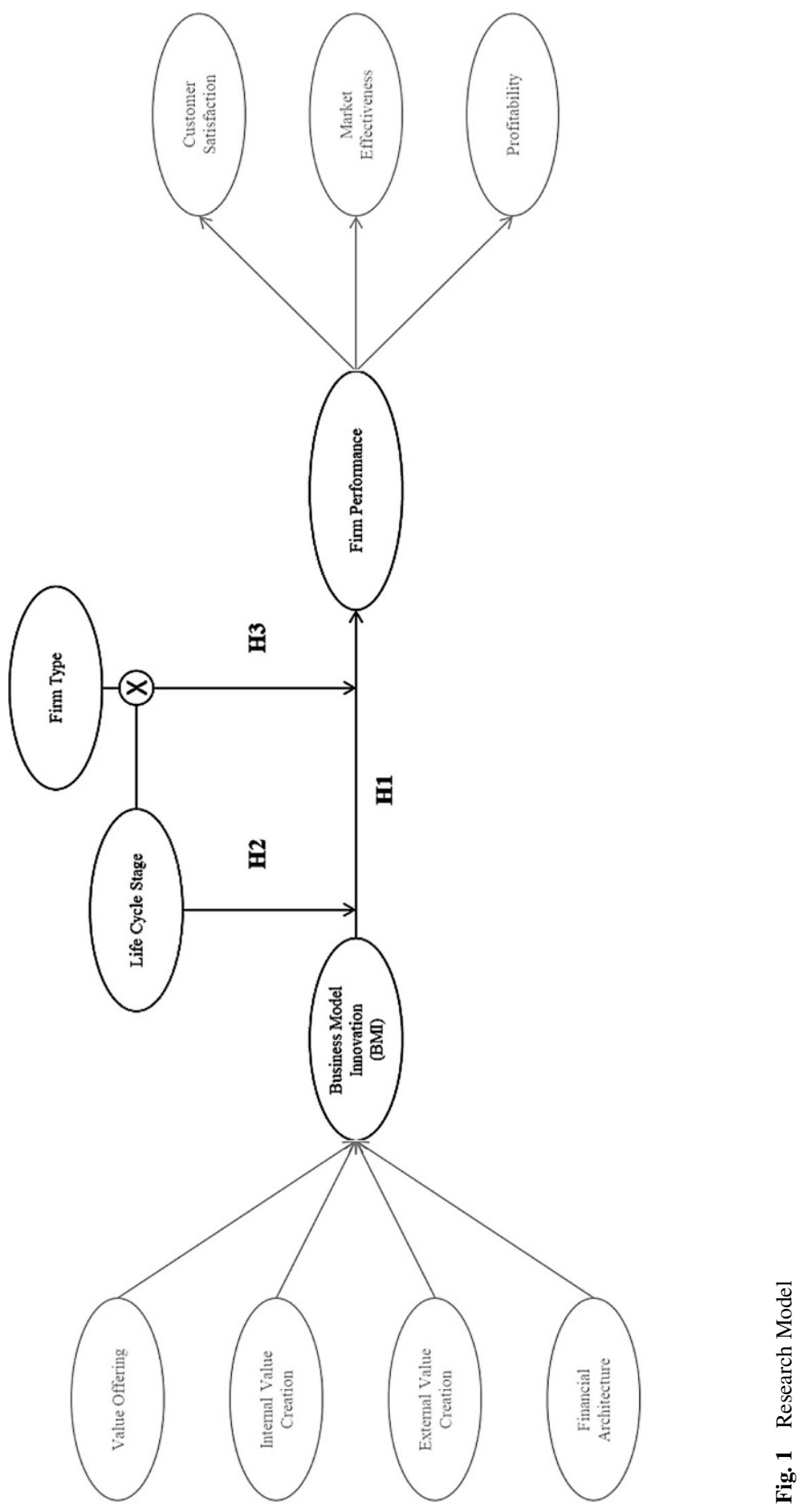


their early stages normally focus on prototyping, thereby enhancing the design of products and establishing a first production process (Gaibraith 1982). However, the main introduction of the product into a market happens at a later stage of the life cycle where the venture is more mature and established (Lumpkin and Dess 1995).

Therefore, we assume the following-

H3: The relationship between BMI and firm performance in early and late life cycle stages differs for product- and service-oriented firm types, namely

H3a: In case of product-oriented ventures, the performance effect of BMI is significantly higher in later than in earlier stages

H3b: In case of service-oriented ventures, the performance effect of BMI is significantly higher in earlier than in the later stages

The proposed research model is depicted in Fig. 1.

\section{Data and Analysis}

\subsection{Data and Sample}

In order to answer our research question, we collected data from ventures in German-speaking countries via a cross-sectional research design. With this research design we respond to a former call of Foss and Saebi (2017) who have suggested "to collect cross-sectional data on business model changes and regress those data against business or corporate performance" (p. 212). Cross-sectional designs have been proven to be a valid approach when investigating the link between BMI and venture performance (e.g., Futterer et al. 2020). Yet, cross-sectional designs always have some limitations with regard to establishing causality. In order to alleviate confounding effects surrounding causality that may arise due to a delay of BMI effects on performance outcomes, we assessed the independent variable of BMI at the time of business formation, and the respective dependent variable "firm performance" at the time of the survey. Our sample needs to consist of the key decision makers within their respective ventures, which are considered to be the top management team or the founder(s) of the venture. This is necessary since the key decision makers are those who shape a firm's strategic orientation (Talke et al. 2011) and, hence, the business model. We, therefore, invited entrepreneurs from the most prominent entrepreneurship directories in Germany (e.g., Bundesverband Deutsche Startups, Gründerszene.de, deutsche-startups.de), Switzerland, Austria, and Lichtenstein (Angellist) to participate in our study in 2017. We collected data via a self-administered survey in the months from April to June, including the first approach and one reminder email. We sent an Email to 3884 individual entrepreneurs containing the link to our online-survey or, when no direct contact information was available, to the venture's e-mail address and included the information that had to be forwarded to the key decision maker. We advised the respondents to think about their focal venture when answering the question-bearing in mind that entrepreneurs might 
Table 2 Descriptive Statistics and Inter-Construct Correlations

\begin{tabular}{llllllllll}
\hline & Mean & SD & 1 & 2 & 3 & 4 & 5 & 6 & 7 \\
\hline $\begin{array}{l}\text { 1. Firm Perfor- } \\
\text { mance }\end{array}$ & 4.55 & 1.124 & 1 & - & - & - & - & - & - \\
$\begin{array}{l}\text { 2. Business } \\
\text { Model Innova- }\end{array}$ & 4.24 & 1.035 & $0.373^{* *}$ & 1 & - & - & - & - & - \\
tion & & & & & & & & & \\
3. Lifecycle Stage & 1.27 & 0.444 & $0.329^{* *}$ & 0.058 & 1 & - & - & - & - \\
4. Company Size & 1.79 & 1.356 & $0.193^{* *}$ & 0.087 & $0.335^{* *}$ & 1 & - & - & - \\
$\begin{array}{l}\text { 5. Education } \\
\text { 6. Age }\end{array}$ & 5.70 & 0.916 & 0.060 & -0.034 & -0.056 & 0.042 & 1 & - & - \\
7. Gender & 34.63 & 9.780 & 0.034 & 0.076 & 0.063 & 0.114 & 0.084 & 1 & - \\
\hline
\end{tabular}

Notes: **Correlation is significant at the 0.01 level (2-tailed)

have more than one venture. Thereby, 268 questionnaires were returned to us. In sum, eighteen returned questionnaires had significant missing values and straightliners that we deleted, thereby resulting in 250 respondents and an overall response rate of $6.9 \%$. On average, the 250 ventures were founded in 2014 ( 3 years old) and conducted mostly business in the IT or service industry, which we assessed by the NACE (Nomenclature statistique des activités économiques dans la Communauté européenne) scale. NACE is a four-digit classification of economic activities in the European Community and the participants were asked to self-categorize their venture. Since the service industry has proven to be an adequate research context for studies in the BMI context (Laudien and Pesch 2019), we also consider our sample as appropriate for our investigation. $61.60 \%$ of all ventures had less than 5 employees, $19.60 \%$ had 6-10 employees, $9.60 \%$ had $11-15$ employees and $9.20 \%$ had more than 16 employees. The average founder in our study is thirty-four years old, male (84\%), obtained a university degree, has about 5 years of start-up experience, funded about 2.40 prior start-ups of which 0.55 failed. Concerns about survival bias are mitigated by the fact that every company can be listed in the public entrepreneurship database. Consequently, immature and young companies are also included. Table 2 presents descriptive statistics and zero-order correlations among all variables used in the analyses.

\subsection{Variables and Method}

We drew on established measures (see the Appendix for the main constructs and items) and applied seven-point Likert-type scales except where otherwise stated. We also pre-tested the questionnaire with a group of twelve experts, namely $\mathrm{PhD}$ researchers working in the economics department at university, thereby ensuring face validity and clarity (Churchill 1979).

Business model innovation Business Model Innovation is operationalized as a molar third-order hierarchical construct adapted from Futterer et al. (2018) with four formative second-order elements (Chin 2010): (1) value offering, (2) internal value creation, (3) external value creation, and (4) financial architecture, enclosing 
thirty-two items that Futterer et al. (2018) derived from established scales. The first element, value offering architecture, builds on the following scales: the noveltycentered business model design by Zott and Amit (2007, 2008), product superiority to the customer by Lee and Colarelli O'Connor (2003), and market newness by Dahlqvist and Wiklund (2012). The items for the second element, internal value creation architecture, are adapted from Gatignon et al. (2002), whereas the third item, external value creation architecture, was operationalized with items adapted by the market newness scales of Lee and Colarelli O'Connor (2003), as well as supplier involvement of Chen and Paulraj (2004). Finally, the fourth element, financial architecture, mainly builds on items adapted by Spieth and Schneider (2016), and supplemented by items from Chesbrough (2007), Dubosson-Torbay et al. (2002), as well as Yunus et al. (2010). We asked the founders to think about the moment of the foundation of the company and indicate how innovative their business model was. All items were measured according to a seven-point Likert scale anchored by "strongly disagree" and "strongly agree."

Firm Performance In general, new ventures do not need to publicize their financial data in financial reports (Wang et al. 2017) and surveying the key informants of the new ventures is a common approach (Anderson and Eshima 2013; Kraus et al. 2012). In accordance with this, we assessed firm performance via the respondents' subjective assessments; they were taken from a synthesis used by Vorhies and Morgan (2005) and comprise previous measures regarding their customer satisfaction (Fornell et al. 1996), profitability (Morgan et al. 2002), and market effectiveness (Vorhies and Morgan 2003) and are commonly used in effect-side research of BMI (e.g., Balboni et al. 2019; Nunes and Do Val Pereira 2020). In studies that are based on the key-informant approach due to the absence of mandatory financial reports this scale entails all components a key informant, such as the founder of the venture, is able to assess. All scales were designed as seven-point scales and we estimated overall firm performance as a reflective second-order construct, comprising the three first-order latent performance factors, thereby building a type I hierarchical component model (Hair et al. 2018).

Organizational Life Cycle Stage The moderating variable in our research model, organizational life cycle stage, was operationalized by using the scale of Brettel et al. (2012) who adapted a five-stage classification scheme from Lumpkin and Dess (1995). In accordance with this, we followed the approach of Brettel et al. (2012) and provided an explanatory sentence for each stage. The five stages included (1) startup/conception and development, (2) commercialization/market entry, (3) growth, (4) consolidation, and (5) maturity/diversification. Similar to Brettel et al. (2012), as well as Engelen et al. (2010), we built two groups, namely early and later stages. The first one included the stages (1) startup/conception and development, as well as (2) commercialization/market entry. The latter one incorporated the last three stages (3) growth, (4) consolidation, and (5) maturity/diversification. Table 3 gives an overview of the stage classifications. 
Table 3 Classification of Life Cycle Stages

\begin{tabular}{lll}
\hline $\begin{array}{l}\text { Organizational } \\
\text { Life Cycle Stage } \\
\text { (nominal moder- } \\
\text { ator) }\end{array}$ & $\begin{array}{l}\text { A firm moves through various stages during its evolution. } \\
\text { Please choose the stage which best describes your company }\end{array}$ & $\begin{array}{l}\text { Classification } \\
\text { in earlier and } \\
\text { later stages }\end{array}$ \\
\hline $\begin{array}{l}\text { Startup/ } \\
\text { conception and } \\
\text { development }\end{array}$ & $\begin{array}{l}\text { Within this company, the primary focus of our activities is on } \\
\text { product development and design, securing adequate financial } \\
\text { resources, and developing the market }\end{array}$ & Earlier Stages \\
$\begin{array}{l}\text { Commercialization/ } \\
\text { market entry }\end{array}$ & $\begin{array}{l}\text { Our company has a product that performs well and meets } \\
\text { a need in the marketplace. It has some revenues and some back- } \\
\text { log of orders. We have the capability to produce and sell, but } \\
\text { we have yet to firmly establish the company in the market }\end{array}$ & \\
& $\begin{array}{l}\text { Our company is characterized by high growth rates in sales. } \\
\text { The major internal focus is around issues of how to produce, } \\
\text { sell, and distribute the products in volume }\end{array}$ & Later Stages \\
Oonsolidation & $\begin{array}{l}\text { Our growth rate slows to a level consistent with market growth. } \\
\text { The primary focus of our activities is to attain profitability }\end{array}$ & \\
while maintaining growth momentum & \\
Maturity/ & $\begin{array}{l}\text { Within this company, the major internal activities include di- } \\
\text { versification efforts. We develop second or third generation } \\
\text { products or totally new product lines and work on the penetra- } \\
\text { tion of new geographic markets }\end{array}$ & \\
& & \\
\hline
\end{tabular}

Control Variables The relationship between BMI and performance depends on several variables for which we included control variables: age, sex, and education of the key respondents as well as firm size measured according to the number of employees. Although all the firms included in our study were relatively young ventures, the firm size might still influence the relationship between BMI and firm performance.

Common Method Bias In order to control for common method bias, procedural and statistical remedies were combined (Podsakoff et al. 2012). We applied proximal and psychological separation between our independent and dependent variable to reduce the respondents' ability to use a similar response pattern (Podsakoff et al. 2003). Statistical remedies included Harman's single factor test (Podsakoff et al. 2003), the Lindell-Whitney marker variable test (Lindell and Whitney 2001), and Kock's collinearity test (Kock 2015). All the independent and dependent variables were included in an exploratory factor analysis, resulting in a total variance of $35.55 \%$, that is below the common threshold of 50\% (Podsakoff et al. 2003). Next, we applied the Lindell-Whitney marker variable test by integrating the measurement inventory of team trust (Bansal et al. 2004) in the model as a theoretically unrelated latent variable (Lindell and Whitney 2001). The highest path coefficient turned out to be 0.15 , which is below the common threshold of 0.30. In addition, we applied a full collinearity test and found that all the variance inflation factors (VIFs) of the latent constructs in our model were not higher than 3.30 (Kock 2015). This indicates that common method variance should not be a concern in our model. 
Statistical Procedures We used structural equation modeling (SEM) to test our research model as this statistical technique allows assessing complex models with different relationships simultaneously (Reinartz et al. 2009). More specifically, we applied partial least squares (PLS) SEM that combines indicators to build composite variables (Lohmöller 1989), which are designed to be the proxies for the constructs under investigation (Rigdon 2016). We have chosen PLS-SEM over covariance-based techniques for several reasons. First, since our study focuses on prediction rather than exploration, indeterminacy is less suitable in a covariancebased approach and more suitable in a PLS approach (e.g. Dijkstra 2014). Second and most important, contrary to CB-SEM approaches, PLS-SEM is capable of modeling type IV higher-order constructs (Chin 2010), which are present in our research model. PLS-SEM has recently been applied to entrepreneurship studies (e.g. Radosevic and Yoruk 2013), in BMI research (Futterer et al. 2018), innovation research (Heidenreich et al. 2016), and to other management topics (for an overview, see Hair et al. 2011). For statistical analyses, SmartPLS 3 (Ringle et al. 2015) was used to estimate the inner and outer model parameters by applying a path weighting scheme (Chin 1998). We also employed non-parametric bootstrapping (Chin 1998; Tenenhaus et al. 2005) with 5000 replications and mean replacement as missing valuealgorithm, as well as individual-level change pre-processing, to obtain the standard errors of the estimates.

The higher-order latent variable BMI was set up by using the hierarchical component model approach (Lohmöller 1989; Tenenhaus et al. 2005). In order to handle the measurement issues of higher-order models in PLS-SEM, researchers can apply the repeated indicators approach, the two-stage approach, or the hybrid approach (Becker et al. 2012). In a simulation study, Becker et al. (2012) found that the repeated indicators approach provides better results when it comes to parameter estimates and lower-order construct scores than the other two techniques. Only in certain cases, the approach is particularly problematic: For example, when assessing reflective-formative and formative-formative hierarchical component models (HCM) or when the higher-order construct (HOC) has one or more antecedent latent variables (Becker et al. 2012). Similar to our research model, the reflective-formative-formative BMI construct is exogenous and the dependent variable-firm performance-is a reflective-reflective HCM; we draw in both cases on the repeated indicators approach. It assigns all indicators of the lower-order constructs to the measurement model of the HOC (Lohmöller 1989; Wold 1982) and can also be applied to thirdorder HCM (e.g., Wetzels et al. 2009). Nevertheless, additional technical considerations need to be considered. First, the indicators at the lower level should not vary strongly when it comes to their number (Becker et al. 2012); second, the measurement models of the HOCs needs to be evaluated in terms of the relationship with their lower-order components (LOC); third, this necessitates additional attention to the collinearity, significance, and relevance of the relationships between the HOCs and LOCs (Hair et al. 2018). We now proceed to evaluate the structural and the measurement models. 


\section{Results}

\subsection{Evaluation of the Measurement Model}

In a first step, we evaluated the hierarchical measurement models of the constructs under investigation, thereby following the criteria and procedure pointed out by Hair et al. (2017). The eight first-order constructs of the molar higher-order construct BMI, as well as the three first-order constructs of the dependent variable firm performance, all have a reflective nature, which means that internal consistency reliability, convergent validity, and discriminant validity need to be evaluated (Hair et al. 2017). In terms of internal consistency and reliability, composite reliability values all exceed the threshold of 0.70 (Henseler et al. 2009) and the same applies for the Cronbach's alpha values, which are all above 0.70 . When it comes to convergent validity, all the indicator loadings of the reflective constructs are well above the threshold value of 0.70 and further analysis shows that the indicator loadings squared are above 0.50 (Hair et al. 2017). The average variance extracted values are all above the required minimum level of 0.50 (Fornell and Larcker 1981). In terms of discriminant validity, the values of the heterotrait-monotrait ratio of correlations (HTMT) — with the highest one turning out to be 0.862 - are also below the threshold of 0.9 (Gold et al. 2001; Teo et al. 2008). As stated above, in terms of HOCs, the measurement models are evaluated according to their relationship with its lower-order components, thereby accounting for the same evaluation criteria and thresholds. Consequently, the HOC firm performance, which is likewise a reflective construct, was assessed and the above stated measurement criteria were all met. However, in reflective-reflective or formative-reflective HCMs conceptual and empirical redundancies are expected and, hence, discriminant validity between HOCs and LOCs is of no relevance (Hair et al. 2018). In a next step, the measurement criteria of the second-level constructs-that is, the four business model elements, as well as the first-level construct BMI itself, which are all operationalized as formative constructs-are assessed in terms of their relationships with their corresponding LOCs. Consequently, the measurements models are evaluated with regards to potential collinearity issues, as well as the significance and relevance of formative indicators (Chin 2010). In terms of collinearity, the VIFs were assessed (Cassel et al. 1999; Diamantopoulos and Winklhofer 2001) and found to be uniformly below the threshold value of 5 (Hair et al. 2013). We, therefore, conclude that collinearity is not an issue in this model. Next we analyzed the outer weights for their significance and relevance by applying a complete bootstrapping procedure using 5000 bootstraps (Hair et al. 2017). In terms of significance levels, we found that all the formative constructs' relationships with their LOCs are significant at a $1 \%$ level. All criteria in terms of formative measurement models are therefore met. Appendices 1-4 and Fig. 2 give an overview of the measurement models and their indicators. Considering the results of all the reflective and formative constructs, we found that they exhibit satisfactory levels of quality. Therefore, we could proceed with the evaluation of the structural model. 


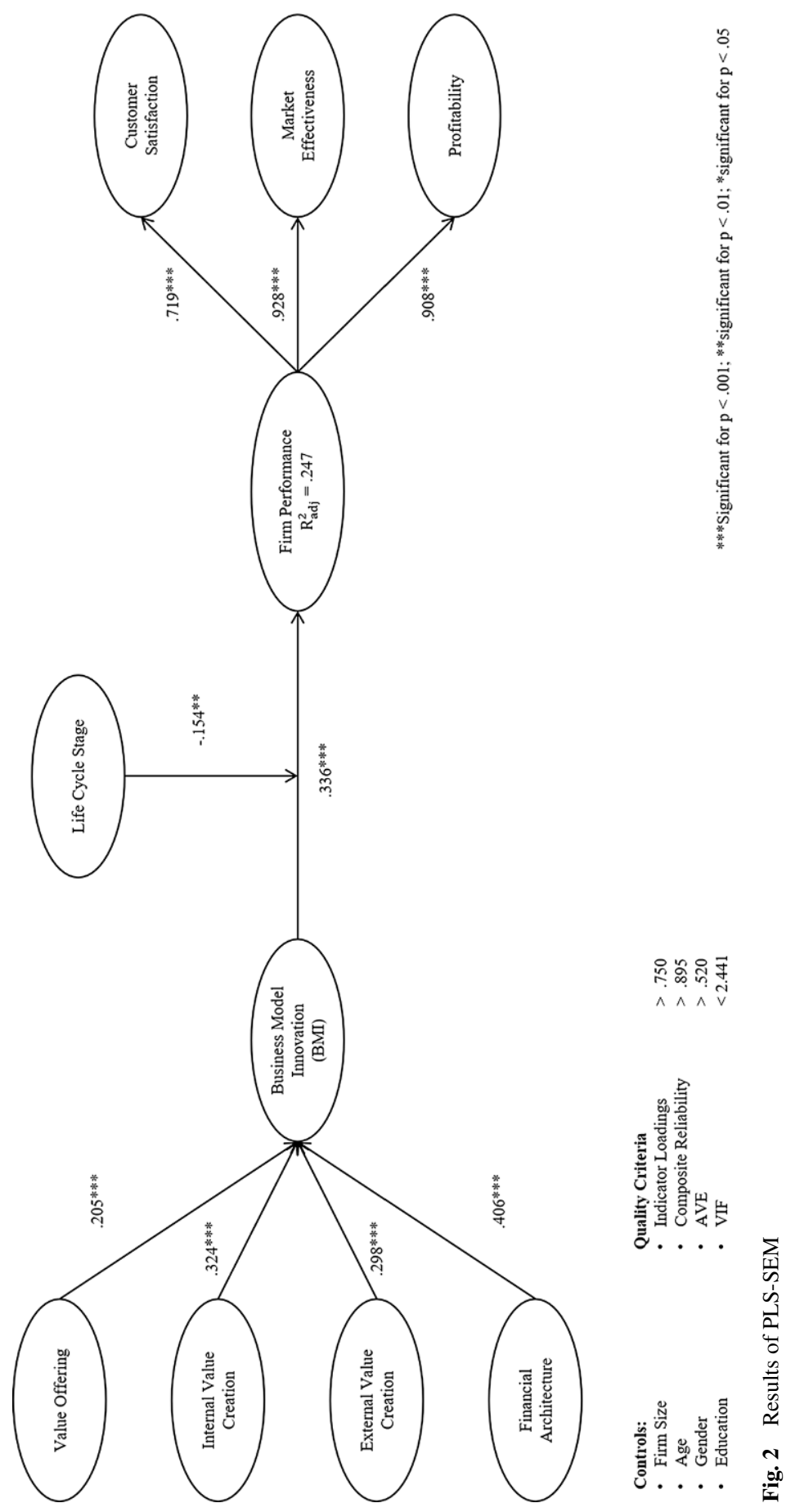




\subsection{Evaluation of the Structural Model}

The main research goal of this study was to empirically examine the relationship between BMI and firm performance. We, therefore, collected primary data and used SmartPLS 3 (Ringle et al. 2015) to test the hypotheses by examining the path coefficients and significances of the structural model. Fig. 2 illustrates the results of the structural model. Again, we followed the procedure outlined by Hair et al. (2017). With respect to the inner model, no VIF value exceeded the threshold of 5-in fact, the highest value turned out to be 2.441, thereby indicating that multicollinearity should not be a concern. The R-squared value in the structural model for the relationship between BMI and firm performance turned out to be 0.247 with an effect size $\mathrm{f}^{2}$ of 0.159 . The blindfolding procedure resulted in $\mathrm{Q}$-squared values above 0 for all endogenous constructs, thereby indicating predictive relevance. BMI has a positive effect on firm performance $(\beta=0.336, p<0.001)$, thereby confirming Hypothesis 1 . Furthermore, the life cycle stage of a firm negatively moderates the positive relationship of BMI with firm performance $(\beta=-0.154, p<0.01)$, thereby supporting Hypothesis 2 . We also studied the moderating relationship by using a separate interaction analysis. Thereby, we used latent variable scores and standardized the predictors prior to the analysis to account for multicollinearity (Aiken and West 1991). Table 4 and Fig. 3 show the results of the analysis. The two-way interaction of BMI and life cycle stage is significant and negative $(\beta=-0.483, p=0.019)$.

In a next step, we tested for differences between product- and service-oriented BMIs and we again conducted two separate interaction analyses, one for productoriented and another for service-oriented firms. The interaction analysis shows that

Table 4 Overview of the Moderating Effects of Life Cycle Stages

\begin{tabular}{lll}
\hline Main Effect & $\begin{array}{l}\text { Interaction Term } \\
\text { Path Coefficient }\end{array}$ & T-Value \\
\hline BMI $\rightarrow$ firm performance & -0.483 & -2.349 \\
\hline
\end{tabular}

Interaction term $=B M I$ and life cycle stage

Fig. 3 Illustration of the Moderating Effect of Life Cycle Stages

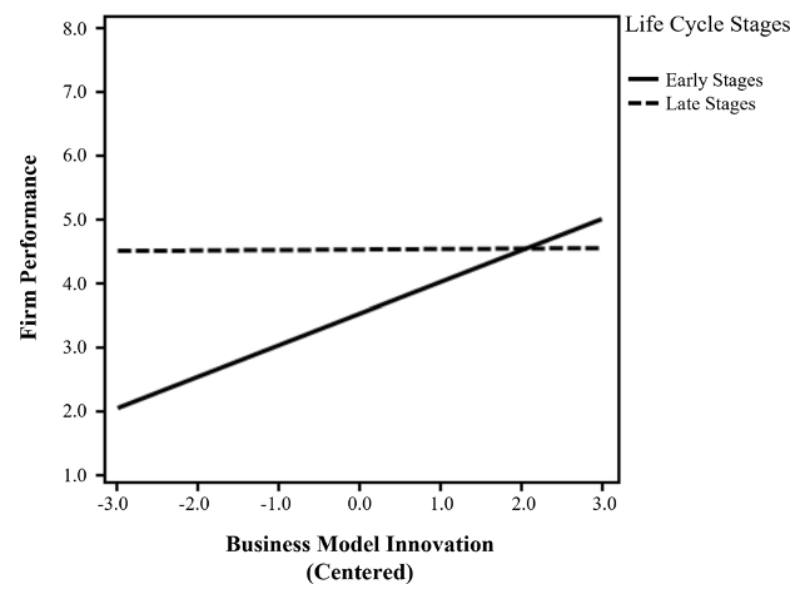


Table 5 Overview of the Moderating Effects of Life Cycle Stages in Different Firm Types

\begin{tabular}{llc}
\hline Type of Firms & Interaction Term & \\
& Path Coefficient & T-Value \\
\hline Product-oriented firms & -0.435 & -1.024 \\
Service-oriented firms & -0.529 & -2.266 \\
\hline
\end{tabular}

Interaction term $=$ type of firms and life cycles stage

a

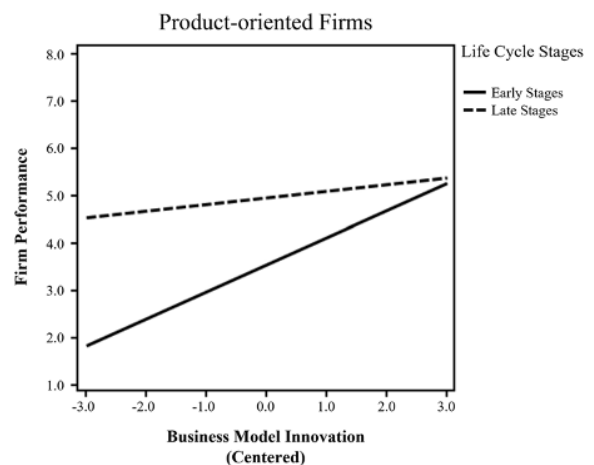

b

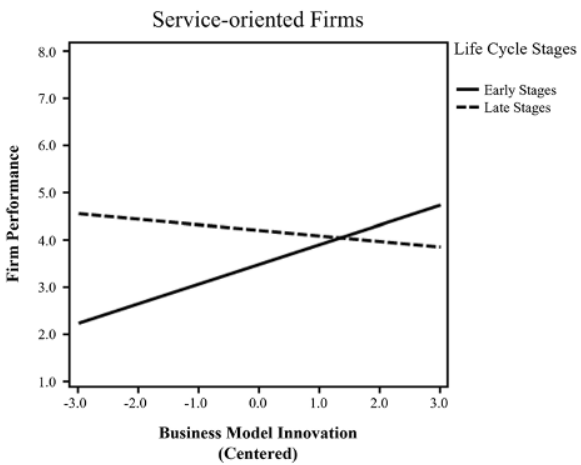

Fig. 4 Illustration of Moderating Effects of Life Cycle Stages in Different Firm Types. a Product-oriented firms. b Service-oriented firms

product- and service-oriented ventures exhibit different performance implications across life cycle stages. However, as Table 5 and Fig. 4 indicate, the difference between early and late stages is not statistically significant in product-oriented ventures $(\beta=-0.435$, n. s.) and therefore, Hypotheses $3 \mathrm{a}$ is not supported. On the contrary, in the case of service-oriented ventures, the performance effect of BMI is significantly higher in the earlier than in the later stages $(\beta=-0.529, p=0.025)$, thereby providing support for Hypotheses $3 \mathrm{~b}$.

\subsection{Additional Analysis}

In addition to our research framework, we have calculated an additional analysis as we wanted to determine the relative importance of each element of BMI in early and late life cycle stages. It has been noted that the often stated, yet vaguely described relationship between BMI and performance relationship is difficult to study, due to its complexity (Foss and Saebi 2017). This complexity stems from the "multiple complex links" (p. 212) between the business model elements and the performance implications that are not only intertwined, but also unfold differently over time. In addition, previous studies have also identified that elements of BMI have a different impact on performance (Schneider et al. 2013). In order to determine the innovation contribution of each business model element in each life cycle stage, we conducted four separate interaction analyses. Table 6 and Fig. 5 show the empirical results and graphic illustration of how each BMI element takes effect on performance in different life cycle stages. 
Table 6 Overview of the Moderating Effects of Life Cycle Stages in Elements

\begin{tabular}{lll}
\hline Business Model Innovation Elements & Interaction Term & \\
& Path Coefficient & T-Value \\
\hline Value offering & -0.317 & -1.693 \\
Internal value creation & -0.412 & -2.242 \\
External value creation & -0.434 & -2.817 \\
Financial architecture & -0.219 & -1.546 \\
\hline
\end{tabular}

Interaction term = type of business model innovation element and life cycle stage

a

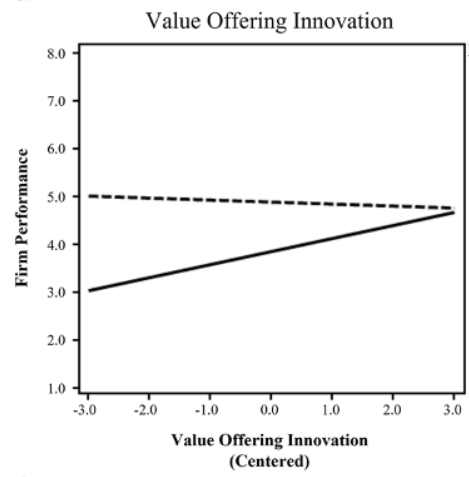

C

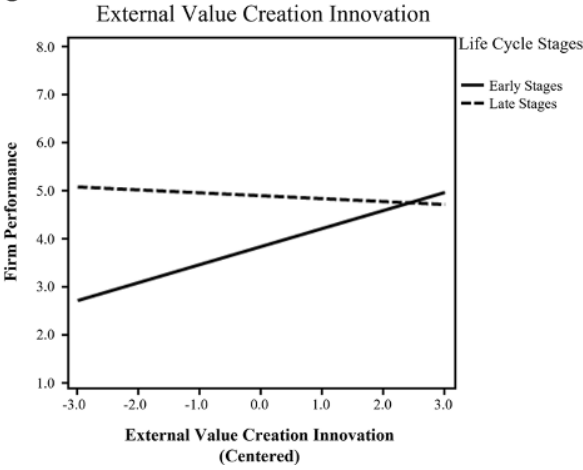

b

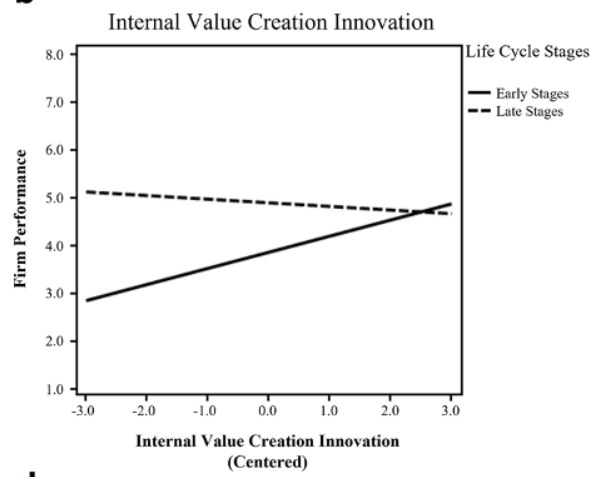

d

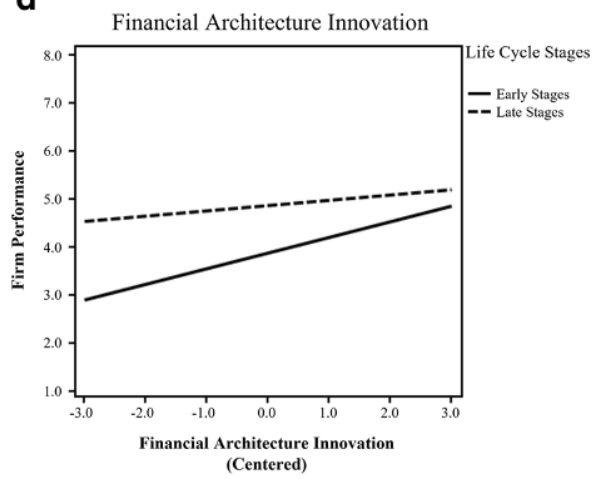

Fig. 5 Illustration of Moderating Effects of Life Cycle Stages in Elements. a Value Offering Innovation. b Internal Value Creation Innovation. c External Value Creation Innovation. d Financial Architecture Innovation

\section{Discussion}

\subsection{Theoretical Implications}

Academic research has, thus far, claimed that BMI is a strong driver of firm performance (Foss and Saebi 2017). However, an important, but largely overlooked research issue is if and to which extent BMI differs in firm performance across different life cycle stages, namely the early and late stages of a venture's life. Hence, this study strives to add to BMI and life cycle theory by making the following con- 
tributions: (1) Our research confirms recent findings on the positive impact of BMI on firm performance, (2) it provides first empirical evidence about the moderating role of life cycle stages on the relationship between positive BMI and performance, and (3) it investigates for the first time how this relationship differs for product- and service-oriented firms.

First, this study found evidence for the hypothesized positive relationship between BMI and firm performance. This finding is in line with previous research in the academic realm (Brettel et al. 2012; Cucculelli and Bettinelli 2015; Futterer et al. 2018; Kim and Min 2015; Zott and Amit 2007). We contribute to current literature by confirming that more innovation in business models will, indeed, result in higher performance (Foss and Saebi 2017).

Second, the life cycle stage's moderation of a venture brings an important factor into the discussion about the performance advantages of BMI. We thereby extend and challenge extant literature on the outcomes of BMI (Cucculelli and Bettinelli 2015; Zott and Amit 2007) by providing - for the first time, to the best of our knowledge-empirical evidence for the impact of BMI on firm performance in early and late life cycle stages. More specifically, the more innovative a business model becomes, the higher are the performance implications for ventures in their earlier stages. In accordance with these results, previous studies have demonstrated that BMI leads to firm performance in the earlier stages of entrepreneurial firms (Brettel et al. 2012; Cucculelli and Bettinelli 2015; Zott and Amit 2007). Perhaps the most striking finding is that in the cases of more established ventures; an increase in BMI does not automatically lead to higher rates of performance. This result has not yet been previously described and extends current research on the outcomes of BMI that assumes a positive relationship (Foss and Saebi 2017). Although anecdotal evidence shows that established companies like Xerox, Gilette, or Apple successfully innovated their business model and were rewarded with higher performance rates than before. Our findings suggests that the performance implications are not tied to the innovativeness of the business model. An explanation for this phenomenon might be that BMI in firms in their later life cycle phases is a positive trigger in the beginning, but that the value creation and capture mechanisms do stem from their existing assets rather from the innovativeness of the BMI itself. In contrast to more established firms, newly founded ventures often operate in niche markets, serve other customers than incumbents, employ novel resources, and are in a situation where they can play actively with their new business models (Tucci and Massa 2013). Further, firms in their early stages are highly centralized in their founder (Chandler and Hanks 1994), who is able to monitor and steer the BMI process. A comparison of these results with those of other studies confirms that companies with a high level of control have a higher innovation-input-output ratio (e.g., Duran et al. 2016). In similar vein, compared to their later stages, new ventures are less formalized and departmentalized in their earlier stages (Hanks et al. 1993) and are, therefore, much more flexible (Jaworski and Kohli 1993). After surviving the liability of newness, the business model of firms in their early stages is the central asset for creating and capturing value, and ultimately to generate performance implications. By providing empirical evidence, we extend the life cycle theory with the phenomenon of BMI and 
conclude that relying only on the innovativeness of the implemented business model in the later stage of a venture's life, will not enhance organizational performance.

Third, our results deliver first empirical evidence on how the interaction effect of life cycle stages differs in the case of product- and service-oriented firms. We found contradictory results. In the case of service-oriented ventures, a more innovative business model especially pays off in early stages, but performance declines during the later stages like we expected. However, in the case of product-oriented ventures, our results show that BMI is important in both stages with no statistical difference between early and late stages. A possible explanation might be that in the event of market acceptance, a venture's main goal is to establish itself in the market (Abernathy and Utterback 1982; Moore and Tushman 1982) and in later stages, ventures aim to maintain their market position by developing a second generation of their product (Kazanjian 1988; Moore and Tushman 1982). In both cases, an innovative business model designed around their focal products might help leverage their customer adoption. Besides being the first study to investigate how the relationship between BMI and firm performance differs for product- and service-oriented firms, we also extend existing knowledge with regards to the life cycle theory.

Fourth, when it comes to the individual contribution of business model elements in each life cycle, our findings of the additional analysis are mostly in line with the main analysis. More specifically, the innovation of all business model elements pays off more in a venture's early life than in its later stages; this means that ventures in their early stages need to have greater pressure for BMI, ultimately leading to firm performance. However, in the event of value offering, as well as internal and external value creation, the innovation of the elements in later stages leads to smaller performance implications. A possible explanation might be that firms in their later stages have already gained market acceptance of their offering (Kazanjian 1988; Moore and Tushman 1982), they have gained a status of formalization with efficient and implemented processes (Churchill and Lewis 1983; Gaibraith 1982), and they have established stable relationships with their partners and customers (Masurel and Van Montfort 2006). After gaining stability and reducing uncertainty for the first time, a change in these offerings, processes, and relationships might lead to confusion and inefficiencies, and ultimately to decreased performance. However, an innovation of the financial architecture element contributes to venture performance in both stages. This is in accordance with current research. In the BMI domain, prior research has shown that efficiency-centered business models, that is, business models designed to reduce transaction costs, enhance firm performance (Zott and Amit 2007, 2008), especially in later stages of organizational life (Brettel et al. 2012). By first investigating how business model elements impact on firm performance in different life cycle stages, we extend existing knowledge by adding a more finegrained analysis, which has only been marginally investigated thus far (Schneider and Spieth 2014). Thereby, we laid the groundwork for disentangling the business model construct into its sub-elements with a certain emphasis on the different life cycle stages of ventures. 


\subsection{Managerial Implications}

These findings may help managers and entrepreneurs to understand how to leverage a new business model to success. In line with earlier studies (Cucculelli and Bettinelli 2015; Zott and Amit 2007), research has found that BMI is an important predictor of performance implications in organizations. Our findings show that a more innovative business model makes a stronger contribution toward organizational performance than a less innovative one. A key policy priority for managers should, therefore, be to design and implement an innovative business model. Second, our results show that especially in the early stages of an organization's life cycle, an innovative business model entails a unique selling point and is a key asset in a successful growth process. The more a venture grows, the less important an innovative business model becomes as other factors gain in importance. Within this context, this study shows that the individual life cycle stage of an organization has an important impact on the performance outcomes of BMI and should, therefore, be carefully assessed. Third, our results point out that managers of organizations have to take their firm type-either a product-oriented or a service-oriented venture-into account. According to our findings, especially in the earlier stages, a service-oriented venture has, to a certain extent, emphasize the design and development of a rather innovative business model. In later stages, however, a very innovative business model might lead to decreased performance. In case of product-oriented ventures, an innovative business model is highly important in both stages. In sum: We advise managers and entrepreneurs to not only carefully assess the innovativeness of their ventures' business models, as well as its elements, by, for example, using the measurement inventory of Futterer et al. (2018), but to also assess, respectively, each life cycle stage the venture is currently passing through by using the framework of Kazanjian (1988). Furthermore, the venture's main offering, which is either a service or a product, must be taken into account for the best possible organizational performance outcome.

\section{Limitations and Avenues for Future Research}

The findings derived from this study make several contributions to the current literature. However, as with any study, this one also has its limitations. First, we conducted a cross-sectional investigation of the relationship between BMI and performance in the new ventures domain to empirically examine the positive implications. Although using cross-sectional data is a common approach in BMI research (Futterer et al. 2018), such approach might suffer from several limitations. The most important one for our investigation might be tied to a potential delay of performance effects of BMI. While we did account for potential confounding effects due to such delay within our measurements, future research might replicate our findings employing a longitudinal sample to completely rule out any confounding effect in this regard by establishing true causality. Second, both the independent and dependent variable were assessed by the same instrument, i.e., survey, and respondent. To minimize potential problems due to common method bias, we applied procedural and statistical measures to rule out common method variance as effectively as possible. However, again replicating 
our findings by a longitudinal study with secondary data might provide additional support for our results. Furthermore, in terms of the moderating role of a firm's life cycle stage, a longitudinal design might provide additional insights and a more fine-grained analysis of the complex mechanisms of BMI and the growth process of a firm. Third, in similar vein, we split our dataset into two stages of a venture's life, namely early and late stages. Although it has provided initial insights into the moderating role of lifecycle stages on firm performance during BMI, it also comes with a lack of information. We therefore encourage scholars to examine the growth process of a new venture in each stage to link their individual growth pattern with the relationship between BMI and performance. A more fine-grained analysis might shed more light on the prominent relationship and produces viable insights in the underlying mechanism on how performance effects unfold over time. Forth, our study was not able to account for the amount of structural change brought about by the innovation of a business model in an established company. Although we split our dataset into early and late stages, the latter stage does not resemble established companies, since our dataset entails only young and older new ventures, but not established companies. When it comes to directions for future research, further studies might explore the relationship investigated in established companies with a special emphasis on the stages of maturity, diversification, and decline. This might result in worthwhile contributions to research on the life cycle theory and BMI. Fifth, an arguable weakness of this study is the founders' self-evaluation of performance as a dependent variable, which makes these findings less generalizable. Although new ventures do not need to publicize their financial data (Wang et al. 2017) and surveying the key informants of the new ventures is a common approach (Anderson and Eshima 2013; Kraus et al. 2012), future research might work with secondary data, such as the amount of investments a venture receives during its growth process as an indicator for third-party's trust in its potential to validate and strengthen our findings. 


\section{Appendix}

Table 7 Measurement Validation of Reflective Constructs-Firm Performance

\begin{tabular}{|c|c|c|c|c|}
\hline $\begin{array}{l}\text { Second-Order } \\
\text { Construct }\end{array}$ & $\begin{array}{l}\text { First-Order } \\
\text { Construct }\end{array}$ & Item & $\begin{array}{l}\text { Loading } \\
\left(\lambda_{i}\right)\end{array}$ & $\begin{array}{l}\text { Sig. } \\
\text { (t-value) }\end{array}$ \\
\hline \multirow{12}{*}{$\begin{array}{l}\text { Firm } \\
\text { performance } \\
A V E=0.571 \\
C R=0.939\end{array}$} & \multirow{4}{*}{$\begin{array}{l}\text { Customer } \\
\text { satisfaction } \\
A V E=0.682 \\
C R=0.895\end{array}$} & $\begin{array}{l}\text { Delivering value to your cus- } \\
\text { tomers }\end{array}$ & 0.850 & 29.270 \\
\hline & & $\begin{array}{l}\text { Delivering what your cus- } \\
\text { tomers want }\end{array}$ & 0.746 & 15.622 \\
\hline & & Retaining valued customers & 0.855 & 41.127 \\
\hline & & $\begin{array}{l}\text { Market share growth relative to } \\
\text { competitors }\end{array}$ & 0.846 & 47.805 \\
\hline & \multirow{4}{*}{$\begin{array}{l}\begin{array}{l}\text { Market } \\
\text { effectiveness }\end{array} \\
A V E=0.773 \\
C R=0.931\end{array}$} & Acquiring new customers & 0.866 & 41.701 \\
\hline & & Growth in sales revenue & 0.922 & 86.593 \\
\hline & & Market effectiveness & 0.872 & 43.891 \\
\hline & & $\begin{array}{l}\text { Increasing sales to existing } \\
\text { customers }\end{array}$ & 0.856 & 45.514 \\
\hline & \multirow{4}{*}{$\begin{array}{l}\text { Profitability } \\
A V E=0.850 \\
C R=0.958\end{array}$} & Business unit profitability & 0.904 & 56.758 \\
\hline & & Return on investment (ROI) & 0.942 & 82.997 \\
\hline & & Return on sales (ROS) & 0.935 & 72.291 \\
\hline & & Reaching financial goals & 0.907 & 57.302 \\
\hline
\end{tabular}


Table 8 Measurement Validation of Reflective Constructs-Business Model Innovation

\begin{tabular}{|c|c|c|c|c|c|}
\hline $\begin{array}{l}\text { Third- } \\
\text { Order Con- } \\
\text { struct }\end{array}$ & $\begin{array}{l}\text { Second- } \\
\text { Order Con- } \\
\text { struct }\end{array}$ & $\begin{array}{l}\text { First-Order } \\
\text { Construct }\end{array}$ & Item & $\begin{array}{l}\text { Loading } \\
\left(\lambda_{i}\right)\end{array}$ & $\begin{array}{l}\text { Sig. } \\
\text { (t-value) }\end{array}$ \\
\hline \multirow{16}{*}{$\begin{array}{l}\text { Business } \\
\text { Model } \\
\text { Innovation } \\
V I F=1.042\end{array}$} & \multirow[t]{8}{*}{$\begin{array}{l}\text { Value } \\
\text { offering } \\
V I F=1.441\end{array}$} & \multirow{4}{*}{$\begin{array}{l}\text { Products/ } \\
\text { services } \\
A V E=0.689 \\
C R=0.898\end{array}$} & $\begin{array}{l}\text {... products, services, or com- } \\
\text { binations of both that are } \\
\text { offered }\end{array}$ & 0.882 & 55.480 \\
\hline & & & $\begin{array}{l}\ldots \text { products and/or services } \\
\text { that are provided }\end{array}$ & 0.879 & 48.505 \\
\hline & & & ... value elements offered & 0.800 & 27.195 \\
\hline & & & $\begin{array}{l}\ldots \text { needs not yet covered by } \\
\text { the market }\end{array}$ & 0.751 & 20.319 \\
\hline & & \multirow{4}{*}{$\begin{array}{l}\text { Target } \\
\text { market } \\
A V E=0.722 \\
C R=0.912\end{array}$} & $\begin{array}{l}\text {... customer groups that have } \\
\text { been addressed }\end{array}$ & 0.885 & 54.592 \\
\hline & & & $\begin{array}{l}\text {... customer segments that } \\
\text { have been approached }\end{array}$ & 0.896 & 54.388 \\
\hline & & & ... market position taken & 0.751 & 19.728 \\
\hline & & & ... defined (sales) market & 0.859 & 43.989 \\
\hline & \multirow{8}{*}{$\begin{array}{l}\text { Internal } \\
\text { value } \\
\text { creation } \\
V I F=1.805\end{array}$} & \multirow{4}{*}{$\begin{array}{l}\text { Resources/ } \\
\text { competencies } \\
A V E=0.864 \\
C R=0.962\end{array}$} & $\begin{array}{l}\ldots \text { resources and competen- } \\
\text { cies that have been utilized }\end{array}$ & 0.893 & 38.920 \\
\hline & & & $\begin{array}{l}\text {... resources and competen- } \\
\text { cies that have been applied }\end{array}$ & 0.941 & 103.715 \\
\hline & & & $\begin{array}{l}\text {... resources and competen- } \\
\text { cies that have been used }\end{array}$ & 0.941 & 103.047 \\
\hline & & & $\begin{array}{l}\text {... resources and competen- } \\
\text { cies that have been deployed }\end{array}$ & 0.942 & 103.586 \\
\hline & & \multirow{4}{*}{$\begin{array}{l}\text { Value } \\
\text { structure } \\
A V E=0.781 \\
C R=0.935\end{array}$} & $\begin{array}{l}\text {... organizational structures } \\
\text { that have been applied }\end{array}$ & 0.863 & 47.680 \\
\hline & & & $\begin{array}{l}\text {... internal processes that have } \\
\text { been utilized }\end{array}$ & 0.867 & 40.396 \\
\hline & & & $\begin{array}{l}\ldots \text { value creation structures } \\
\text { that have been deployed }\end{array}$ & 0.906 & 59.982 \\
\hline & & & $\begin{array}{l}\text {... value creation activities } \\
\text { used }\end{array}$ & 0.899 & 66.280 \\
\hline
\end{tabular}


Table 9 Measurement Validation of Reflective Constructs-Business Model Innovation (continued)

\begin{tabular}{|c|c|c|c|c|c|}
\hline $\begin{array}{l}\text { Third- } \\
\text { Order } \\
\text { Construct }\end{array}$ & $\begin{array}{l}\text { Second- } \\
\text { Order } \\
\text { Construct }\end{array}$ & $\begin{array}{l}\text { First-Order } \\
\text { Construct }\end{array}$ & Item & $\begin{array}{l}\text { Loading } \\
\left(\lambda_{i}\right)\end{array}$ & $\begin{array}{l}\text { Sig. } \\
\text { (t-value) }\end{array}$ \\
\hline \multirow[t]{15}{*}{$\begin{array}{l}\text { Business } \\
\text { Model } \\
\text { Innovation }\end{array}$} & \multirow[t]{7}{*}{$\begin{array}{l}\text { External } \\
\text { value } \\
\text { creation } \\
V I F=1.760\end{array}$} & \multirow[t]{3}{*}{$\begin{array}{l}\text { Partners/ } \\
\text { stakeholders } \\
A V E=0.837 \\
C R=0.953\end{array}$} & $\begin{array}{l}\text {... existing partnerships } \\
\text {... cooperation partners inte- } \\
\text { grated in the value creation } \\
\text { process }\end{array}$ & $\begin{array}{l}0.884 \\
0.922\end{array}$ & $\begin{array}{l}41.938 \\
65.583\end{array}$ \\
\hline & & & $\begin{array}{l}\text {... partnerships established in } \\
\text { the value creation process }\end{array}$ & 0.948 & 112.844 \\
\hline & & & $\begin{array}{l}\text {... external partners integrated } \\
\text { in the internal value creation } \\
\text { activities }\end{array}$ & 0.904 & 54.333 \\
\hline & & \multirow{4}{*}{$\begin{array}{l}\text { Distribution } \\
\text { channels } \\
A V E=0.861 \\
C R=0.961\end{array}$} & ... sales channels used & 0.918 & 79.385 \\
\hline & & & $\begin{array}{l}\text {... distribution channels that } \\
\text { were developed }\end{array}$ & 0.938 & 87.614 \\
\hline & & & $\begin{array}{l}\text {... chains of distribution that } \\
\text { were established }\end{array}$ & 0.926 & 60.660 \\
\hline & & & $\begin{array}{l}\text {... trade channels that were } \\
\text { utilized }\end{array}$ & 0.929 & 73.194 \\
\hline & \multirow{8}{*}{$\begin{array}{l}\text { Financial } \\
\text { architec- } \\
\text { ture } \\
V I F=2.009\end{array}$} & \multirow{4}{*}{$\begin{array}{l}\text { Revenue } \\
\text { mecha- } \\
\text { nisms } \\
A V E=0.867 \\
C R=0.963\end{array}$} & ... revenue structures used & 0.934 & 69.915 \\
\hline & & & $\begin{array}{l}\text {... revenue mechanisms that } \\
\text { were utilized }\end{array}$ & 0.935 & 73.854 \\
\hline & & & $\begin{array}{l}\text {... revenue model that was } \\
\text { established }\end{array}$ & 0.937 & 76.736 \\
\hline & & & $\begin{array}{l}\text {... revenue logic that was ap- } \\
\text { plied }\end{array}$ & 0.919 & 55.384 \\
\hline & & \multirow{4}{*}{$\begin{array}{l}\text { Cost } \\
\text { structure } \\
A V E=0.913 \\
C R=0.977\end{array}$} & $\begin{array}{l}\text {... cost structures that were } \\
\text { applied }\end{array}$ & 0.953 & 107.753 \\
\hline & & & ... cost logic that was utilized & 0.952 & 112.119 \\
\hline & & & $\begin{array}{l}\ldots \text { cost model that was estab- } \\
\text { lished }\end{array}$ & 0.964 & 145.110 \\
\hline & & & ... cost mechanisms used & 0.954 & 80.535 \\
\hline
\end{tabular}




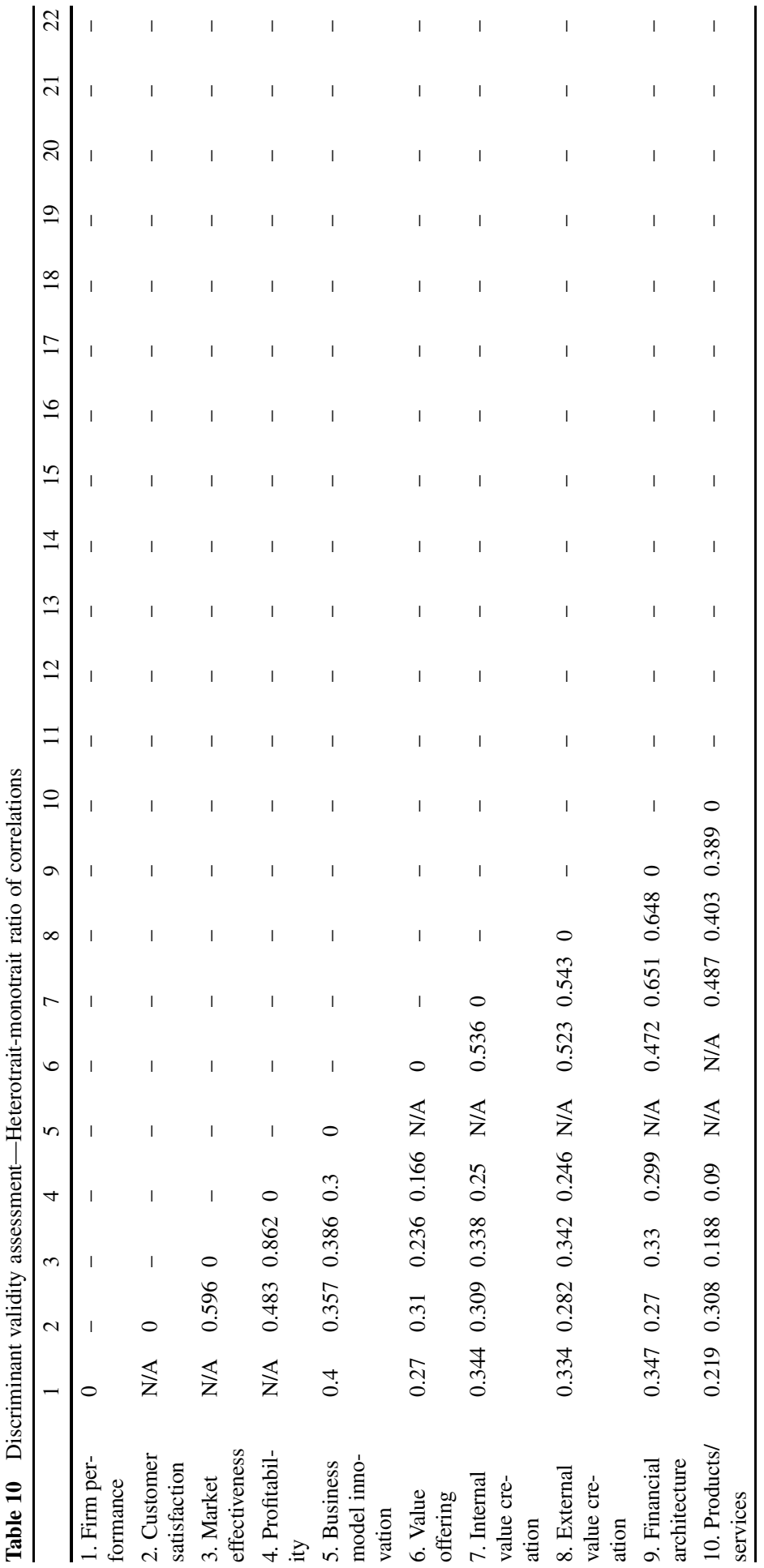




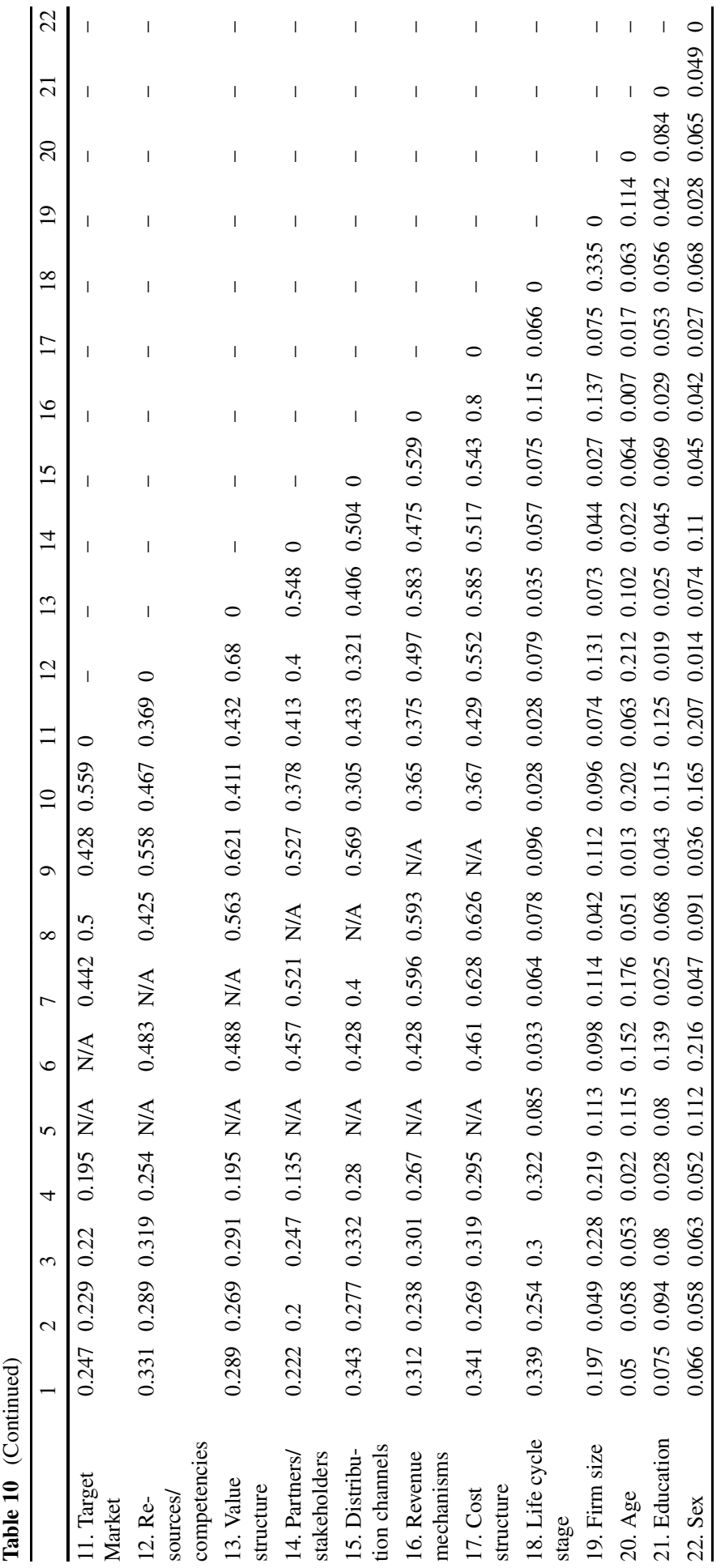


Funding Open Access funding enabled and organized by Projekt DEAL.

Open Access This article is licensed under a Creative Commons Attribution 4.0 International License, which permits use, sharing, adaptation, distribution and reproduction in any medium or format, as long as you give appropriate credit to the original author(s) and the source, provide a link to the Creative Commons licence, and indicate if changes were made. The images or other third party material in this article are included in the article's Creative Commons licence, unless indicated otherwise in a credit line to the material. If material is not included in the article's Creative Commons licence and your intended use is not permitted by statutory regulation or exceeds the permitted use, you will need to obtain permission directly from the copyright holder. To view a copy of this licence, visit http://creativecommons.org/licenses/by/4. $0 \%$

Conflict of interest E. Freisinger, S. Heidenreich, P. Spieth and C. Landau declare that they have no competing interests.

\section{References}

Abernathy, W.J., and J.M. Utterback. 1982. Patterns in industrial innovation. In Readings in the management of innovation, ed. M.L. Tushman, W.L. Moore, 132-150. Boston: Pitman Press.

Abrahamsson, J., A.A. Maga, and C. Nicol. 2019. The effect of business model innovation on share prices-A study of US listed technology firms. Journal of Business Models 7:37-52. https://doi. org/10.5278/ojs.jbm.v7i2.2141.

Afuah, A. 2014. Business model innovation: concepts, analysis and cases. New York: Routledge.

Aiken, L.S., and S.G. West. 1991. Multiple regression: testing and interpreting interactions. Thousand Oaks: SAGE.

Amit, R., and C. Zott. 2012. Creating value through business model innovation. MIT Sloan Management Review 53:41-49.

Anderson, B.S., and Y. Eshima. 2013. The influence of firm age and intangible resources on the relationship between entrepreneurial orientation and firm growth among Japanese SMEs. Journal of Business Venturing 28:413-429. https://doi.org/10.1016/j.jbusvent.2011.10.001.

Anwar, M. 2018. Business model innovation and SMEs performance-Does competitive advantage mediate? International Journal of Innovation Management 22:1-31. https://doi.org/10.1142/S1363919618 500573.

Baden-Fuller, C., and S. Haefliger. 2013. Business models and technological innovation. Long Range Planning 46:419-426. https://doi.org/10.1016/j.lrp.2013.08.023.

Balboni, B., G. Bortoluzzi, R. Pugliese, and A. Tracogna. 2019. Business model evolution, contextual ambidexterity and the growth performance of high-tech start-ups. Journal of Business Research 99:115-124. https://doi.org/10.1016/j.jbusres.2019.02.029.

Bansal, H.S., P.G. Irving, and S.F. Taylor. 2004. A three-component model of customer commitment to service providers. Journal of the Academy of Marketing Science 32:234-250. https://doi.org/10.1177/ 0092070304263332.

Becker, J.M., K. Klein, and M. Wetzels. 2012. Hierarchical latent variable models in PLS-SEM: guidelines for using reflective-formative type models. Long Range Planning 45:359-394. https://doi.org/ 10.1016/j.lrp.2012.10.001.

Bock, A.J., T. Opsahl, G. George, and D.M. Gann. 2012. The effects of culture and structure on strategic flexibility during business model innovation. Journal of Management Studies 49:279-305. https:// doi.org/10.1111/j.1467-6486.2011.01030.x.

Bocken, N.M.P., S. Short, P. Rana, and S. Evans. 2013. A value mapping tool for sustainable business modelling. Corporate Governance 13:482-497. https://doi.org/10.1108/CG-06-2013-0078.

Bouncken, R.B., and V. Fredrich. 2016. Business model innovation in alliances: successful configurations. Journal of Business Research 69:3584-3590. https://doi.org/10.1016/j.jbusres.2016.01.004.

Brettel, M., S. Strese, and T.C. Flatten. 2012. Improving the performance of business models with relationship marketing efforts-An entrepreneurial perspective. European Management Journal 30:85-98. https://doi.org/10.1016/j.emj.2011.11.003.

Bucherer, E., U. Eisert, and O. Gassmann. 2012. Towards systematic business model innovation: lessons from product innovation management. Creativity and Innovation Management 21:183-198. https:// doi.org/10.1111/j.1467-8691.2012.00637.x. 
Calantone, R.J., K. Chan, and A.S. Cui. 2006. Decomposing product Innovativeness and its effects on new product success. Journal of Product Innovation Management 23:408-421. https://doi.org/10.1111/j. 1540-5885.2006.00213.x.

Carayannis, E.G., S. Sindakis, and C. Walter. 2015. Business model innovation as lever of organizational sustainability. The Journal of Technology Transfer 40:85-104. https://doi.org/10.1007/s10961-0139330-y.

Carr, J.C., K.S. Haggard, K.M. Hmieleski, and S.A. Zahra. 2010. A study of the moderating effects of firm age at internationalization on firm survival and short-term growth. Strategic Entrepreneurship Journal 4:183-192. https://doi.org/10.1002/sej.90.

Casadesus-Masanell, R., and J.E. Ricart. 2010. From strategy to business models and onto tactics. Long Range Planning 43:195-215. https://doi.org/10.1016/j.lrp.2010.01.004.

Casadesus-Masanell, R., and F. Zhu. 2013. Business model innovation and competitive imitation: the case of sponsor-based business models. Strategic Management Journal 34:464-482. https://doi.org/10. 1002/smj.2022.

Cassel, C., P. Hackl, and A.H. Westlund. 1999. Robustness of partial least-squares method for estimating latent variable quality structures. Journal of Applied Statistics 26:435-446. https://doi.org/10.1080/ 02664769922322.

Chandler, G.N., and S.H. Hanks. 1994. Founder competence, the environment, and venture performance. Entrepreneurship Theory and Practice 18:77-89. https://doi.org/10.1177/104225879401800306.

Chen, I.J., and A. Paulraj. 2004. Towards a theory of supply chain management: the constructs and measurements. Journal of Operations Management 22:119-150. https://doi.org/10.1016/j.jom.2003.12. 007.

Chesbrough, H. 2007. Business model innovation: it's not just about technology anymore. Strategy \& Leadership 35:12-17. https://doi.org/10.1108/10878570710833714.

Chesbrough, H., and R.S. Rosenbloom. 2002. The role of the business model in capturing value from innovation: evidence from Xerox Corporation's technology spin-off companies. Industrial and Corporate Change 11:529-555. https://doi.org/10.1093/icc/11.3.529.

Chin, W.W. 1998. The partial least squares approach for structural equation modeling. In Methodology for business and management. Modern methods for business research, ed. G.A. Marcoulides, 295-336. Mahwah: Erlbaum.

Chin, Wynne W. 2010. How to write up and report PLS analyses. In Handbook of partial least squares, ed. V. Esposito Vinzi, W.W. Chin, J. Henseler, and H. Wang, 655-690. Berlin, Heidelberg: Springer. https://doi.org/10.1007/978-3-540-32827-8_29.

Churchill, G.A. 1979. A paradigm for developing better measures of marketing constructs. Journal of Marketing Research 16:64. https://doi.org/10.2307/3150876.

Churchill, N., and V. Lewis. 1983. The five stages of small business growth. Harvard Business Review 61:30-50. https://doi.org/10.1016/0024-6301(87)90071-9.

Cillo, P., L.M. De Luca, and G. Troilo. 2010. Market information approaches, product innovativeness, and firm performance: an empirical study in the fashion industry. Research Policy 39:1242-1252. https:// doi.org/10.1016/j.respol.2010.06.004.

Clauss, T. 2017. Measuring business model innovation: conceptualization, scale development, and proof of performance. $R \& D$ Management 47:385-403. https://doi.org/10.1111/radm.12186.

Clauss, T., M. Abebe, C. Tangpong, and M. Hock. 2019a. Strategic agility, business model innovation, and firm performance: an empirical investigation. IEEE Transactions on Engineering Management PP https://doi.org/10.1109/TEM.2019.2910381.

Clauss, T., T. Kesting, and J. Naskrent. 2019b. A rolling stone gathers no moss: the effect of customers' perceived business model innovativeness on customer value co-creation behavior and customer satisfaction in the service sector. $R \& D$ Management 49:180-203. https://doi.org/10.1111/radm.12318.

Cooper, R.G., and E.J. Kleinschmidt. 1987. New products: what separates winners from losers? The Journal of Product Innovation Management 4:169-184. https://doi.org/10.1016/0737-6782(87)90002-6.

Cucculelli, M., and C. Bettinelli. 2015. Business models, intangibles and firm performance: evidence on corporate entrepreneurship from Italian manufacturing SMEs. Small Business Economics 45:329-350. https://doi.org/10.1007/s11187-015-9631-7.

Cucculelli, M., and V. Peruzzi. 2020. Post-crisis firm survival, business model changes, and learning: evidence from the Italian manufacturing industry. Small Business Economics 54:459-474. https:// doi.org/10.1007/s11187-018-0044-2.

Dahlqvist, J., and J. Wiklund. 2012. Measuring the market newness of new ventures. Journal of Business Venturing 27:185-196. https://doi.org/10.1016/j.jbusvent.2010.12.001. 
Danneels, E., and E.J. Kleinschmidtb. 2001. Product innovativeness from the firm's perspective: its dimensions and their relation with project selection and performance. Journal of Product Innovation Management 18:357-373. https://doi.org/10.1111/1540-5885.1860357.

Demil, B., and X. Lecocq. 2010. Business model evolution: in search of dynamic consistency. Long Range Planning 43:227-246. https://doi.org/10.1016/j.lrp.2010.02.004.

Demil, B., X. Lecocq, J.E. Ricart, and C. Zott. 2015. Introduction to the SEJ special issue on business models: business models within the domain of strategic entrepreneurship. Strategic Entrepreneurship Journal 9:1-11. https://doi.org/10.1002/sej.1194.

Denicolai, S., M. Ramirez, and J. Tidd. 2014. Creating and capturing value from external knowledge: the moderating role of knowledge intensity. R\&D Management 44:248-264.

Denyer, D., and D. Tranfield. 2009. Producing a systematic review. In The SAGE handbook of organizational research methods, ed. D.A. Buchanan, A. Bryman, 671-689. London: SAGE.

Dewald, J., and F. Bowen. 2010. Storm clouds and silver linings: responding to disruptive innovations through cognitive resilience. Entrepreneurship: Theory and Practice 34:197-218. https://doi.org/10. 1111/j.1540-6520.2009.00312.x.

Diamantopoulos, A., and H.M. Winklhofer. 2001. Index construction with formative indicators: an alternative to scale development. Journal of Marketing Research 38:269-277. https://doi.org/10.1509/jmkr. 38.2.269.18845.

Dijkstra, T.K. 2014. PLS' Janus face-Response to Professor Rigdon's 'rethinking partial least squares modeling: in praise of simple methods. Long Range Planning 47:146-153. https://doi.org/10.1016/j. lrp.2014.02.004.

Dodge, H.R., S. Fullerton, and J.E. Robbins. 1994. Stage of the organizational life cycle and competition as mediators of problem perception for small businesses. Strategic Management Journal 15:121-134. https://doi.org/10.1002/smj.4250150204.

Dubosson-Torbay, M., A. Osterwalder, and Y. Pigneur. 2002. E-business model design, classification, and measurements. Thunderbird International Business Review 44:5. https://doi.org/10.1002/tie.1036.

Duran, P., N. Kammerlander, M. van Essen, and T. Zellweger. 2016. Doing more with less: innovation input and output in family firms. Academy of Management Journal 59:1224-1264. https://doi.org/10. 5465/amj.2014.0424.

Ebel, P.A., U. Bretschneider, and J.M. Leimeister. 2016. Can the crowd do the job? Exploring the effects of integrating customers into a company's business model innovation. International Journal of Innovation Management 20:1650071. https://doi.org/10.1142/S1363919616500717.

Engelen, A., M. Brettel, and F. Heinemann. 2010. The antecedents and consequences of a market orientation: the moderating role of organisational life cycles. Journal of Marketing Management 20:515-547. https://doi.org/10.1080/02672570903458680.

Fornell, C., and D.F. Larcker. 1981. Evaluating structural equation models with unobservable variables and measurement error. Journal of Marketing Research 18:39. https://doi.org/10.2307/3151312.

Fornell, C., M.D. Johnson, E.W. Anderson, J. Cha, and B.E. Bryant. 1996. The American customer satisfaction index: nature, purpose, and findings. Journal of Marketing 60:7-18. https://doi.org/10.2307/ 1251898.

Foss, N.J., and T. Saebi. 2017. Fifteen years of research on business model innovation: how far have we come, and where should we go? Journal of Management 43:200-227. https://doi.org/10.1177/ 0149206316675927.

Foss, N.J., and T. Saebi. 2018. Business models and business model innovation: between wicked and paradigmatic problems. Long Range Planning 51:9-21. https://doi.org/10.1016/j.lrp.2017.07.006.

Frankenberger, K., and W. Stam. 2020. Entrepreneurial copycats: a resource orchestration perspective on the link between extra-industry business model imitation and new venture growth. Long Range Planning 53:101872. https://doi.org/10.1016/j.1rp.2019.02.005.

França, C.L., G. Broman, K.-H.H. Robèrt, G. Basile, and L. Trygg. 2016. An approach to business model innovation and design for strategic sustainable development. Journal of Cleaner Production 140:1-12. https://doi.org/10.1016/j.jclepro.2016.06.124.

Futterer, F., S. Heidenreich, and P. Spieth. 2020. Is new always better? How business model innovation affects consumers' Adoption behavior. IEEE Transactions on Engineering Management https://doi. org/10.1109/TEM.2020.3014403.

Futterer, F., J. Schmidt, and S. Heidenreich. 2018. Effectuation or causation as the key to corporate venture success? Investigating effects of entrepreneurial behaviors on business model innovation and venture performance. Long Range Planning 51:64-81. https://doi.org/10.1016/j.lrp.2017.06.008.

Gaibraith, J. 1982. The stages of growth. Journal of Business Strategy 3:70-79. https://doi.org/10.1108/ eb038958. 
Garcia, R., and R. Calantone. 2002. A critical look at technological innovation typology and innovativeness terminology: a literature review. Journal of Product Innovation Management 19:110-132. https://doi. org/10.1016/S0737-6782(01)00132-1.

Gatignon, H., M.L. Tushman, W. Smith, and P. Anderson. 2002. A structural approach to assessing innovation: construct development of innovation locus, type, and characteristics. Management Science 48:1103-1122. https://doi.org/10.1287/mnsc.48.9.1103.174.

George, G., and A.J. Bock. 2011. The business model in practice and its implications for entrepreneurship research. Entrepreneurship: Theory and Practice 35:83-111. https://doi.org/10.1111/j.1540-6520. 2010.00424.x.

Gerasymenko, V., D. De Clercq, and H.J. Sapienza. 2015. Changing the business model: effects of venture capital firms and outside CEos on portfolio company performance. Strategic Entrepreneurship Journal 9:79-98. https://doi.org/10.1002/sej.1189.

Gold, A.H., A. Malhotra, and A.H. Segars. 2001. Knowledge management: an organizational capabilities perspective. Journal of Management Information Systems 18:185-214. https://doi.org/10.1080/ 07421222.2001.11045669.

Guo, H., J. Tang, Z. Su, and J.A. Katz. 2017. Opportunity recognition and SME performance: the mediating effect of business model innovation. R\&D Management 47:431-442. https://doi.org/10.1111/radm. 12219.

Guo, H., C. Wang, Z. Su, and D. Wang. 2020. Technology push or market pull? Strategic orientation in business model design and digital start-up performance. Journal of Product Innovation Management 37:352-372. https://doi.org/10.1111/jpim.12526.

Hair, J.F.J., G.T.M. Hult, C.M. Ringle, and M. Sarstedt. 2017. A primer on Partial Least Squares Structural Equation Modeling (PLS-SEM), 2nd edn., Thousand Oaks: SAGE.

Hair, J.F.J., C.M. Ringle, and M. Sarstedt. 2011. PLS-SEM: indeed a silver bullet. Journal of Marketing Theory and Practice 19:139-152. https://doi.org/10.2753/MTP1069-6679190202.

Hair, J.F.J., C.M. Ringle, and M. Sarstedt. 2013. Partial least squares structural equation modeling: rigorous applications, better results and higher acceptance. Long Range Planning 46:1-12. https://doi.org/10. 1016/j.lrp.2013.01.001.

Hair, J.F.J., M. Sarstedt, C.M. Ringle, and S.P. Gudergan. 2018. Advanced issues in partial least squares structural equation modeling. Thousand Oaks: SAGE.

Hanks, S.H., C.J. Watson, E. Jansen, and G.N. Chandler. 1993. Tightening the life-cycle construct: a taxonomic study of growth stage configurations in high-technology organizations. Entrepreneurship: Theory \& Practice 18:5-30.

Heidenreich, S., T. Kraemer, and M. Handrich. 2016. Satisfied and unwilling: exploring cognitive and situational resistance to innovations. Journal of Business Research 69:2440-2447. https://doi.org/10. 1016/j.jbusres.2016.01.014.

Henseler, J., C.M. Ringle, and R.R. Sinkovics. 2009. The use of partial least squares path modeling in international marke tintinting. In Advances in International Marketing, ed. R.R. Sinkovics, P.N. Ghauri, 277-319. Bingley: Emerald.

Hu, B. 2014. Linking business models with technological innovation performance through organizational learning. European Management Journal 32:587-595. https://doi.org/10.1016/j.emj.2013.10.009.

Jaworski, B.J., and A.K. Kohli. 1993. Market orientation: antecedents and consequences. Journal of Marketing 57:53-70. https://doi.org/10.4135/9781452231426.n5.

Johnson, M.W., C.M. Christensen, and H. Kagermann. 2008. Reinventing your business model. Harvard Business Review 86:1-10. https://doi.org/10.1111/j.0955-6419.2005.00347.x.

de Jong, M., and M. van Dijk. 2015. Disrupting beliefs: a new approach to business model innovation. In McKinsey special collection growth and innovation.

Karimi, J., and Z. Walter. 2016. Corporate entrepreneurship, disruptive business model innovation adoption, and its performance: the case of the newspaper industry. Long Range Planning 49:342-360. https://doi.org/10.1016/j.lrp.2015.09.004.

Kastalli, I.V., B. Van Looy, and A. Neely. 2013. Steering manufacturing firms towards service business model innovation. California Management Review 56:100-123.

Kazanjian, R.K. 1988. Relation of dominant problems to stages of growth in technology-based new ventures. Academy of Management Journal 31:257-279.

Kim, S.K., and S. Min. 2015. Business model innovation performance: when does adding a new business model benefit an incumbent? Strategic Entrepreneurship Journal 9:34-57. https://doi.org/10.1002/ sej. 1193.

Kindström, D. 2010. Towards a service-based business model-Key aspects for future competitive advantage. European Management Journal 28:479-490. https://doi.org/10.1016/j.emj.2010.07.002. 
Klein, S., S. Schneider, and P. Spieth. 2021. How to stay on the road? A business model perspective on mission drift in social purpose organizations. Journal of Business Research 125:658-671. https://doi. org/10.1016/j.jbusres.2020.01.053.

Kock, N. 2015. Common method bias in PLS-SEM: a full collinearity assessment approach. International Journal of E-Collaboration 11:1-10. https://doi.org/10.4018/ijec.2015100101.

Konya-Baumbach, E., M.C. Schuhmacher, S. Kuester, and V. Kuharev. 2019. Making a first impression as a start-up: strategies to overcome low initial trust perceptions in digital innovation adoption. International Journal of Research in Marketing 36:385-399. https://doi.org/10.1016/j.ijresmar.2019.01. 008.

Kotha, R., Y. Zheng, and G. George. 2011. Entry into new niches: the effects of firm age and the expansion of technological capabilities on innovative output and impact. Strategic Management Journal 32:1011-1024. https://doi.org/10.1002/smj.915.

Kranich, P., and A. Wald. 2018. Does model consistency in business model innovation matter? A contingency-based approach. Creativity and Innovation Management 27:209-220. https://doi.org/10.1111/ caim. 12247.

Kraus, S., A. Brem, M. Schuessler, F. Schuessler, and T. Niemand. 2017. Innovative born globals: investigating the influence of their business models on international performance. International Journal of Innovation Management 21:1750005. https://doi.org/10.1142/S1363919617500050.

Kraus, S., J.P.C. Rigtering, M. Hughes, and V. Hosman. 2012. Entrepreneurial orientation and the business performance of SMEs: a quantitative study from the Netherlands. Rev. Manag. Sci. 6:161-182. https:// doi.org/10.1007/s11846-011-0062-9.

Kulins, C., H. Leonardy, and C. Weber. 2016. A configurational approach in business model design. Journal of Business Research 69:1437-1441. https://doi.org/10.1016/j.jbusres.2015.10.121.

Lambert, S.C., and R.A. Davidson. 2013. Applications of the business model in studies of enterprise success, innovation and classification: An analysis of empirical research from 1996 to 2010. European Management Journal 31:668-681.

Laudien, S.M., and B. Daxböck. 2017. Understanding the lifecycle of service firm business models: a qualitative-empirical analysis. $R \& D$ Management 47:473-483. https://doi.org/10.1111/radm.12273.

Laudien, S.M., and R. Pesch. 2019. Understanding the influence of digitalization on service firm business model design: a qualitative-empirical analysis. Review of Managerial Science 13:575-587. https:// doi.org/10.1007/s11846-018-0320-1.

Lee, Y., and G. Colarelli O'Connor. 2003. The impact of communication strategy on launching new products: the moderating role of product innovativeness. Journal of Product Innovation Management 20:4-21. https://doi.org/10.1111/1540-5885.t01-1-201002.

Lepak, D.P., K.G. Smith, and M.S. Taylor. 2007. Value creation and value capture: a multilevel perspective. Academy of Management Review 32:180-194. https://doi.org/10.5465/AMR.2007.23464011.

Lindell, M.K., and D.J. Whitney. 2001. Accounting for common method variance in cross-sectional research designs. Journal of Applied Psychology 86:114-121. https://doi.org/10.1037/0021-9010.86.1. 114.

Lohmöller, J.-B. 1989. Latent variable path modeling with partial least squares. Heidelberg: PhysicaVerlag. https://doi.org/10.1007/978-3-642-52512-4.

Lumpkin, G.T., and G.G. Dess. 1995. Simplicity as a strategy-making process: the effects of stage of organizational development and environment on performance. The Academy of Management Journal 38:1386-1407.

Martins, L.L., V.P. Rindova, and B.E. Greenbaum. 2015. Unlocking the hidden value of concepts: a cognitive approach to business model innovation. Strategic Entrepreneurship Journal 9:99-117. https:// doi.org/10.1002/sej.1191.

Massa, L., C.L. Tucci, and A. Afuah. 2017. A critical assessment of business model research. Academy of Management Annals 11:73-104. https://doi.org/10.5465/annals.2014.0072.

Masurel, E., and K. Van Montfort. 2006. Life cycle characteristics of small professional service firms. Journal of Small Business Management 44:461-473. https://doi.org/10.1111/j.1540-627X.2006.00182.x.

Migol, E., O. Tretyak, and A.B. Holm. 2018. Business model design and firm performance. Journal of Business Models 6:54-58. https://doi.org/10.5278/ojs.jbm.v6i2.2464.

Moore, W.L., and M.L. Tushman. 1982. Managing innovation over the product life cycle. In Readings in the management of innovation, ed. M.L. Tushman, W.L. Moore, 131-150. Boston: Pitman Press.

Morgan, N.A., B.H. Clark, and R. Gooner. 2002. Marketing productivity, marketing audits, and systems for marketing performance assessment: Integrating multiple perspectives. Journal of Business Research 55:363-375. https://doi.org/10.1016/S0148-2963(00)00162-4. 
Morris, M., G. Shirokova, and A. Shatalov. 2013. The business model and firm performance: the case of Russian food service ventures. Journal of Small Business Management 51:46-65.

Normann, R., and R. Ramirez. 1993. Designing interactive strategy. Harvard Business Review 71:65-77.

Normann, R., and R. Ramirez. 1994. Designing interactive strategy: from value chain to value constellation. Chichester: John Wiley \& Sons Ltd.

Nunes, M.P., and R. Do Val Pereira. 2020. Business model innovation and business performance in an innovative environment. International Journal of Innovation Management 25:2150036. https://doi. org/10.1142/S1363919621500365.

Osterwalder, A., Y. Pigneur, and T. Clark. 2010. Business model generation: a handbook for visionaries, game changers, and challengers. Hoboken: John Wiley \& Sons Inc.

Osterwalder, A., Y. Pigneur, and C.L. Tucci. 2005. Clarifying business models: origins, present, and future of the concept. Communications of the Association for Information Systems 15:1-25.

Pati, R.K., M.K. Nandakumar, A. Ghobadian, R.D. Ireland, and N. O'Regan. 2018. Business model design-Performance relationship under external and internal contingencies: evidence from SMEs in an emerging economy. Long Range Planning 51:750-769. https://doi.org/10.1016/j.lrp.2018.01.001.

Podsakoff, P.M., S.B. MacKenzie, J.-Y. Lee, and N.P. Podsakoff. 2003. Common method biases in behavioral research: a critical review of the literature and recommended remedies. Journal of Applied Psychology 88:879-903. https://doi.org/10.1037/0021-9010.88.5.879.

Podsakoff, P.M., S.B. MacKenzie, and N.P. Podsakoff. 2012. Sources of method bias in social science research and recommendations on how to control it. Annual Review of Psychology 63:539-569. https:// doi.org/10.1146/annurev-psych-120710-100452.

Porter, M.E. 1985. Competitive advantage: creating and sustaining superior performance. New York: FreePress.

Quinn, R.E., and K. Cameron. 1983. Organizational life cycles and shifting criteria of effectiveness: some preliminary evidence. Management Science 29:33-51.

Radosevic, S., and E. Yoruk. 2013. Entrepreneurial propensity of innovation systems: theory, methodology and evidence. Research Policy 42:1015-1038. https://doi.org/10.1016/j.respol.2013.01.011.

Reinartz, W., M. Haenlein, and J. Henseler. 2009. An empirical comparison of the efficacy of covariancebased and variance-based SEM. International Journal of Market Research 26:332-344. https://doi. org/10.2139/ssrn. 1462666 .

Rigdon, E.E. 2016. Choosing PLS path modeling as analytical method in European management research: a realist perspective. European Management Journal 34:598-605. https://doi.org/10.1016/j.emj.2016. 05.006 .

Ringle, C.M., S. Wende, and J.-M. Becker. 2015. SmartPLS 3

Rosenbusch, N., J. Brinckmann, and A. Bausch. 2011. Is innovation always beneficial? A meta-analysis of the relationship between innovation and performance in SMEs. Journal of Business Venturing 26:441-457. https://doi.org/10.1016/j.jbusvent.2009.12.002.

Roure, J.B., and R.H. Keeley. 1990. Predictors of success in new technology based ventures. Journal of Business Venturing 5:201-220. https://doi.org/10.1016/0883-9026(90)90017-N.

Sabatier, V., A. Craig-Kennard, and V. Mangematin. 2012. When technological discontinuities and disruptive business models challenge dominant industry logics: Insights from the drugs industry. Technological Forecasting and Social Change 79:949-962. https://doi.org/10.1016/j.techfore.2011.12.007.

Saebi, T., L. Lien, and N.J. Foss. 2017. What drives business model adaptation? The impact of opportunities, threats and strategic orientation. Long Range Planning 50:567-581. https://doi.org/10.1016/j. 1rp.2016.06.006.

Schneider, S., and P. Spieth. 2014. Business model innovation and strategic flexibility: insights from an experimental research design. International Journal of Innovation Management 18:1.

Schneider, S., P. Spieth, and T. Clauss. 2013. Business model innovation in the aviation industry. International Journal of Product Development 18:286-310.

Schrauder, S., A. Kock, C.V. Baccarella, and K.I. Voigt. 2018. Takin' care of business models: the impact of business model evaluation on front-end success. Journal of Product Innovation Management 35:410-426. https://doi.org/10.1111/jpim.12411.

Schumpeter, J.A. 1934. The theory of economic development. Cambridge: Harvard University Press.

Smith, K.G., T.R. Mitchell, and C.E. Summer. 1985. Top level management priorities in different stages of the organizational life cycle. Academy of Management Journal 28:799-820. https://doi.org/10.2307/ 256238.

Snihur, Y. 2016. Developing optimal distinctiveness: organizational identity processes in new ventures engaged in business model innovation. Entrepreneurship \& Regional Development 28:259-285. https:// doi.org/10.1080/08985626.2016.1155745. 
Snihur, Y., and J. Tarzijan. 2018. Managing complexity in a multi-business-model organization. Long Range Planning 51:50-63. https://doi.org/10.1016/j.lrp.2017.06.010.

Sorescu, A., R.T. Frambach, J. Singh, A. Rangaswamy, and C. Bridges. 2011. Innovations in retail business models. Journal of Retailing 87:3-16. https://doi.org/10.1016/j.jretai.2011.04.005.

Spieth, P., and S. Schneider. 2016. Business model innovativeness: designing a formative measure for business model innovation. Journal of Business Economics 86:671-696. https://doi.org/10.1007/s11573015-0794-0.

Spieth, P., T. Roeth, and S. Meissner. 2019. Reinventing a business model in industrial networks: Implications for customers' brand perceptions. Industrial Marketing Management 83:275-287. https://doi. org/10.1016/j.indmarman.2019.04.013.

Stinchcombe, A.L. 1965. Social structure and organizations. https://doi.org/10.1016/S0742-3322(00) 17019-6.

Suh, T., O. J. Khan, B. Schnellbächer, and S. Heidenreich. 2020. Strategic Accord and Tension for Business Model Innovation: Examining Different Tacit Knowledge Types and Open Action Strategies. International Journal of Innovation Management 24:2050039. https://doi.org/10.1142/S1363919620500395

Talke, K., S. Salomo, and A. Kock. 2011. Top management team diversity and strategic innovation orientation: the relationship and consequences for Innovativeness and performance. Journal of Product Innovation Management 28:819-832. https://doi.org/10.1111/j.1540-5885.2011.00851.x.

Taran, Y., H. Boer, and P. Lindgren. 2015. A business model innovation typology. Decision Sciences 46:301-331.

Tavassoli, S., and L. Bengtsson. 2018. The role of business model innovation for product innovation performance. International Journal of Innovation Management https://doi.org/10.1142/S13639196185 00615.

Teece, D.J. 2010. Business models, business strategy and innovation. Long Range Planning 43:172-194. https://doi.org/10.1016/j.lrp.2009.07.003.

Tenenhaus, M., V.E. Vinzi, Y.M. Chatelin, and C. Lauro. 2005. PLS path modeling. Computational Statistics and Data Analysis 48:159-205. https://doi.org/10.1016/j.csda.2004.03.005.

Teo, T.S.H., S.C. Srivastava, and L. Jiang. 2008. Trust and electronic government success: an empirical study. Journal of Management Information Systems 25:99-132. https://doi.org/10.2753/MIS07421222250303.

Thornhill, S., and R. Amit. 2003. Learning about failure: bankruptcy, firm age, and the resource-based view. Organization Science 14:497-509. https://doi.org/10.1287/orsc.14.5.497.16761.

Trabucchi, D., L. Talenti, and T. Buganza. 2019. How do big bang disruptors look like? A business model perspective. Technological Forecasting and Social Change 141:330-340. https://doi.org/10.1016/j. techfore.2019.01.009.

Tripsas, M., and G. Gavetti. 2000. Capabilities, cognition, and inertia: evidence from digital imaging. Strategic Management Journal 21:1147-1161. https://doi.org/10.1002/1097-0266(200010/11)21:10/ 11\%3C1147::AID-SMJ128\%3E3.0.CO;2-R.

Tucci, C.L., and L. Massa. 2013. Business model innovation. In The Oxford handbook of innovation management, ed. M. Dodgson, D.M. Gann, and N. Philipps, 420-441. Oxford: Oxford University Press.

Visnjic Kastalli, I., and B. Van Looy. 2013. Servitization: disentangling the impact of service business model innovation on manufacturing firm performance. Journal of Operations Management 31:169-180. https://doi.org/10.1016/j.jom.2013.02.001.

Visnjic, I., F. Wiengarten, and A. Neely. 2016. Only the brave: product innovation, service business model innovation, and their impact on performance. Journal of Product Innovation Management 33:36-52.

Vorhies, D.W., and N.A. Morgan. 2003. A configuration theory assessment of marketing organization fit with business strategy and its relationship with marketing performance. Journal of Marketing 67:100-115. https://doi.org/10.1509/jmkg.67.1.100.18588.

Vorhies, D.W., and N.A. Morgan. 2005. Benchmarking marketing capabilities for sustainable competitive advantage. Journal of Marketing 69:80-94. https://doi.org/10.1509/jmkg.69.1.80.55505.

Wang, T., S. Thornhill, and J.O. De Castro. 2017. Entrepreneurial orientation, legitimation, and new venture performance. Strategic Entrepreneurship Journal 11:373-392. https://doi.org/10.1002/sej.1246.

Wei, Z., X. Song, and D. Wang. 2017. Manufacturing flexibility, business model design, and firm performance. International Journal of Production Economics 193:87-97. https://doi.org/10.1016/j.ijpe. 2017.07.004.

Wei, Z., D. Yang, B. Sun, and M. Gu. 2014. The fit between technological innovation and business model design for firm growth: evidence from China. $R \& D$ Management 44:288-305. 
Wetzels, M., G. Odekerken-Schröder, and C. van Oppen. 2009. Using PLS path modeling for assessing hierarchical construct models: guidelines and empirical illustration. MIS Quarterly 33:177. https:// doi.org/10.2307/20650284.

Wirtz, B.W., O. Schilke, and S. Ullrich. 2010. Strategic development of business models: Implications of the web 2.0 for creating value on the internet. Long Range Planning 43:272-290. https://doi.org/10. 1016/j.1rp.2010.01.005.

Wold, H. 1982. Soft modeling: the basic design and some extensions. In Systems under indirect observation, part II, ed. K.G. Jöreskog, H. Wold, 1-54. Amsterdam: North-Holland.

Yunus, M., B. Moingeon, and L. Lehmann-Ortega. 2010. Building social business models: lessons from the Grameen experience. Long Range Planning 43:308-325.

Zaheer, A., and G.G. Bell. 2005. Benefiting from network position: firm capabilities, structural holes, and performance. Strategic Management Journal 26:809-825. https://doi.org/10.1002/smj.482.

Zahra, S.A., and G. George. 2002. Absorptive capacity: a review, reconceptualization, and extension. Academy of Management Review 27:185-203. https://doi.org/10.5465/AMR.2002.6587995.

Zott, C., and R. Amit. 2007. Business model design and the performance of entrepreneurial firms. Organization Science 18:181-199. https://doi.org/10.1287/orsc.1060.0232.

Zott, C., and R. Amit. 2008. The fit between product market strategy and business model: implications for firm performance. Strategic Management Journal 29:1-26. https://doi.org/10.1002/smj.642.

Zott, C., and R. Amit. 2010. Business model design: an activity system perspective. Long Range Planning 43:216-226. https://doi.org/10.1016/j.1rp.2009.07.004.

Zott, C., and R. Amit. 2013. The business model: a theoretically anchored robust construct for strategic analysis. Strategic Organization 11:403-411. https://doi.org/10.1177/1476127013510466.

Zott, C., R. Amit, and L. Massa. 2011. The business model: recent developments and future research. Journal of Management 37:1019-1042. https://doi.org/10.1177/0149206311406265. 